\section{Analysis of Pre-Retrofit Building and Utility Data}

Duncan Prahl and Robert Beach IBACOS, Inc.

December 2014 


\section{NOTICE}

This report was prepared as an account of work sponsored by an agency of the United States government. Neither the United States government nor any agency thereof, nor any of their employees, subcontractors, or affiliated partners makes any warranty, express or implied, or assumes any legal liability or responsibility for the accuracy, completeness, or usefulness of any information, apparatus, product, or process disclosed, or represents that its use would not infringe privately owned rights. Reference herein to any specific commercial product, process, or service by trade name, trademark, manufacturer, or otherwise does not necessarily constitute or imply its endorsement, recommendation, or favoring by the United States government or any agency thereof. The views and opinions of authors expressed herein do not necessarily state or reflect those of the United States government or any agency thereof.

Available electronically at www.osti.gov/bridge

Available for a processing fee to U.S. Department of Energy and its contractors, in paper, from:

U.S. Department of Energy

Office of Scientific and Technical Information

P.O. Box 62

Oak Ridge, TN 37831-0062

phone: 865.576 .8401

fax: 865.576.5728

email: mailto:reports@adonis.osti.gov

Available for sale to the public, in paper, from:

U.S. Department of Commerce

National Technical Information Service

5285 Port Royal Road

Springfield, VA 22161

phone: 800.553 .6847

fax: 703.605.6900

email: orders@ntis.fedworld.gov

online ordering: www.ntis.gov/ordering.htm 


\title{
Analysis of Pre-Retrofit Building and Utility Data
}

\author{
Prepared for: \\ The National Renewable Energy Laboratory \\ On behalf of the U.S. Department of Energy’s Building America Program \\ Office of Energy Efficiency and Renewable Energy \\ 15013 Denver West Parkway \\ Golden, CO 80401 \\ NREL Contract No. DE-AC36-08GO28308
}

Prepared by:

Duncan Prahl and Robert Beach

IBACOS, Inc.

2214 Liberty Avenue

Pittsburgh, PA 15222

NREL Technical Monitor: Stacey Rothgeb

Prepared under Subcontract No. KNDJ-0-40341-04

December 2014 
The work presented in this report does not represent performance of any product relative to regulated minimum efficiency requirements.

The laboratory and/or field sites used for this work are not certified rating test facilities. The conditions and methods under which products were characterized for this work differ from standard rating conditions, as described.

Because the methods and conditions differ, the reported results are not comparable to rated product performance and should only be used to estimate performance under the measured conditions. 


\section{Contents}

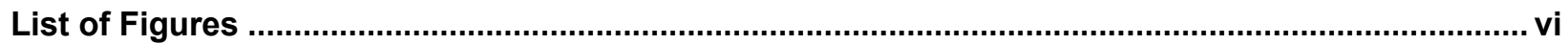

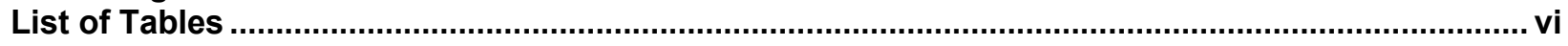

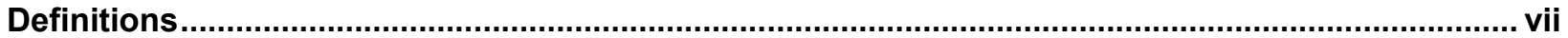

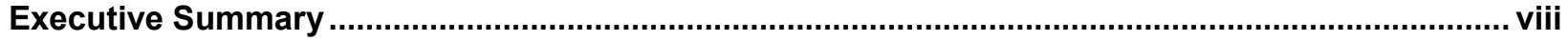

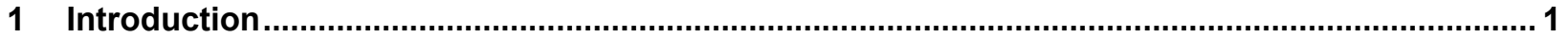

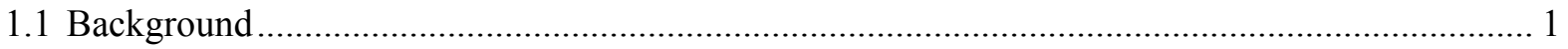

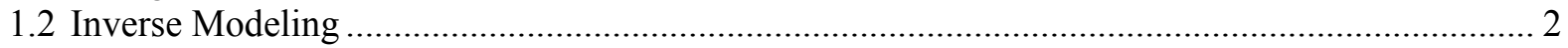

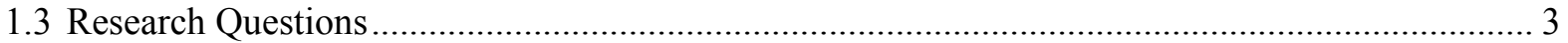

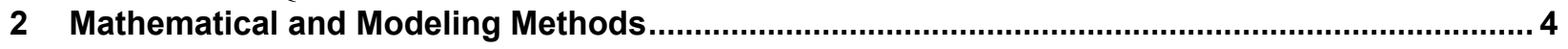

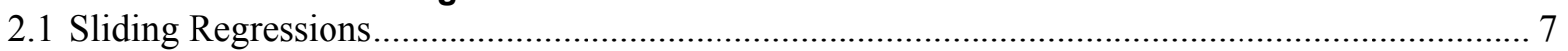

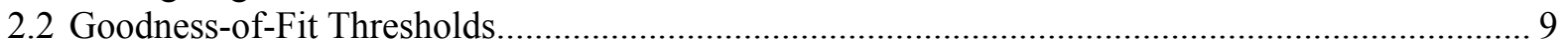

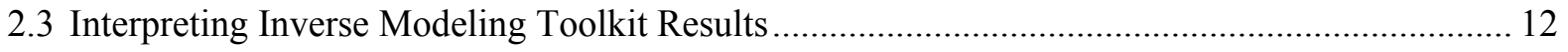

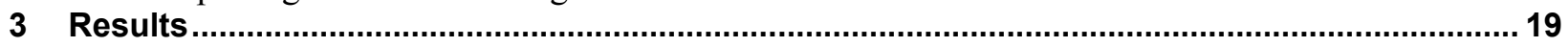

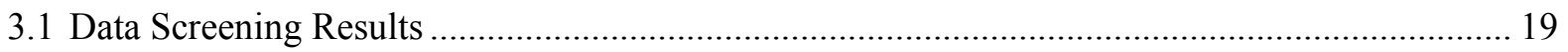

3.2 Grouping by Plan Type, Square Footage, Occupancy, and Orientation ..................................... 24

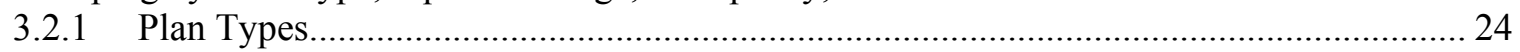

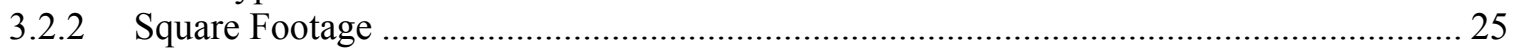

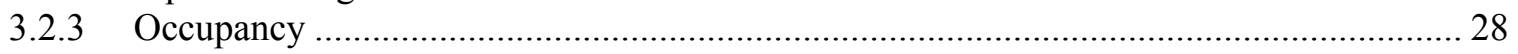

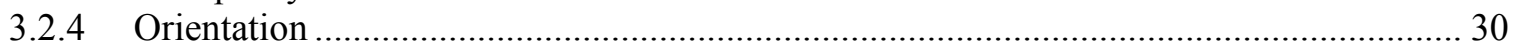

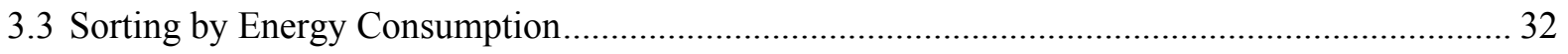

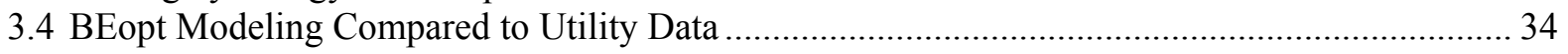

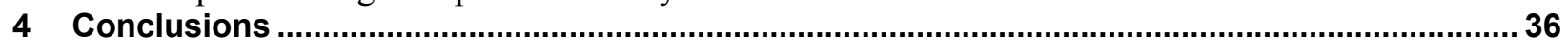

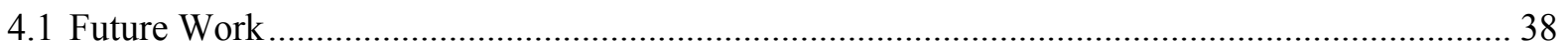

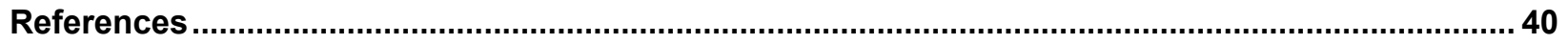




\section{List of Figures}

Figure 1. One home's daily electricity consumption overlaying the community's daily energy consumption distribution

Figure 2. Three years of daily total electricity consumption for one example home ........................ 6

Figure 3. Total daily electricity consumption with interruption for one example home..................... 7

Figure 4. Monthly graphic representation of sliding regression intervals......................................... 7

Figure 5. Example sliding regression results for a single home ................................................... 8

Figure 6. Example sliding regression results with shaded "passing" time intervals ........................ 10

Figure 7. One full year of results for four example homes, low and high energy consumption ...... 13

Figure 8. BEopt to IMT sensitivity analysis results. (HDD is heating degree day.) .......................... 16

Figure 9. GOF measures for unscreened 1-year and 3-year screened averages ............................ 20

Figure 10. Inverse modeling results............................................................................................. 20

Figure 11. Estimated normalized annual energy consumption per end use, with 2011

temperatures

Unless otherwise noted, all figures and photos were created by IBACOS.

\section{List of Tables}

Table 1. GOF Threshold Values per Data Resolution

Table 2. Summary of Sliding Regression Results With Passing GOF Measures, Monthly and Daily 11

Table 3. Final Results for Example Home, Monthly and Daily..................................................... 12

Table 4. BEopt Input Parameters and Baseline Values..................................................................... 15

Table 5. Implications of Five Parameters Derived From BEopt Simulations ...................................... 17

Table 6. Parameters Changed for BEopt Modeling ..................................................................... 18

Table 7. Filtering Iterations, Survival Percentage, and GOF Measures, Daily and Monthly.............. 19

Table 8. Summary of Inverse Modeling Results ...................................................................... 21

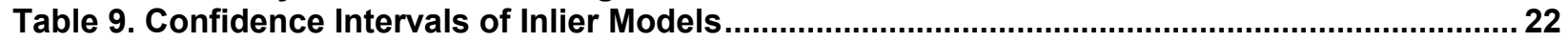

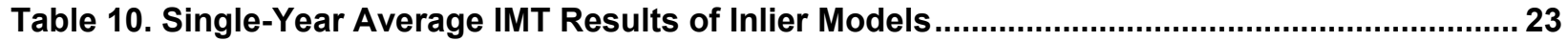

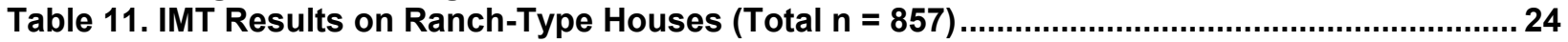

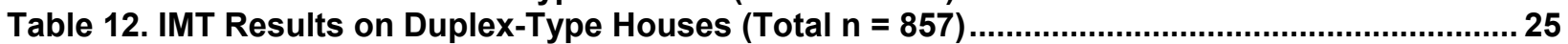

Table 13. Percent Change Between Duplex and Ranch-Type Houses ........................................... 25

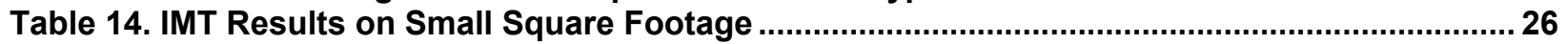

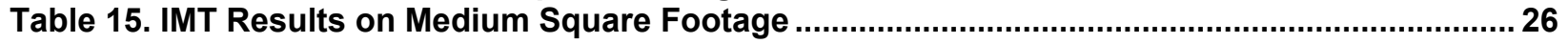

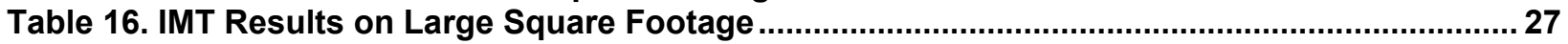

Table 17. Percent Change From Small to Medium Square Footage ............................................. 27

Table 18. Percent Change From Medium to Large Square Footage ................................................... 28

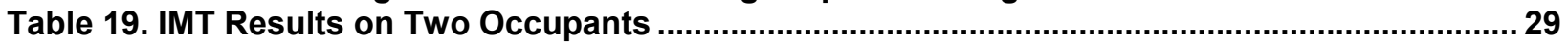

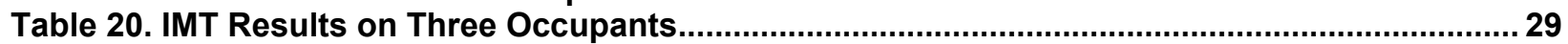

Table 21. Percent Change From Three to Two Occupants ................................................................ 30

Table 22. Percent Change From Monthly to Daily, Two and Three Occupants .................................. 30

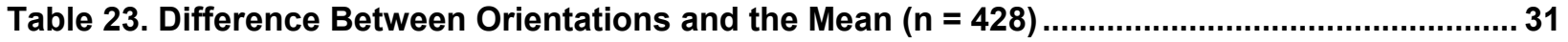

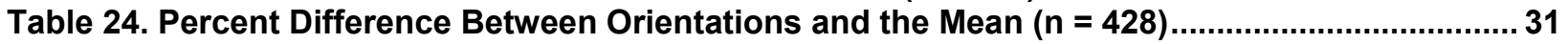

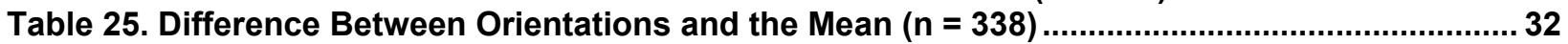

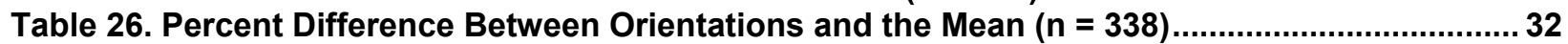

Table 27. Counts and Percentages of Inlier Homes Within Base Load and Cooling Slope Bins ..... 34

Table 28. Comparison of Utility Bill Data and BEopt Simulation IMT Results ....................................35

Table 29. Comparison of Annual Energy Consumption Statistics ...................................................... 35

Unless otherwise noted, all tables were created by IBACOS. 


\section{Definitions}

$\begin{array}{ll}\text { ACH50 } & \text { Air Changes per Hour at 50 Pascals } \\ \text { BEopt }^{\mathrm{TM}} & \text { Building Energy Optimization (software) } \\ \text { BESTEST-EX } & \text { Building Energy Simulation Test for Existing Homes } \\ \text { BPI } & \text { Building Performance Institute, Inc. } \\ \text { CDD } & \text { Cooling Degree Day } \\ \text { COP } & \text { Coefficient of Performance } \\ \text { CV-RMSE } & \text { Coefficient of Variance of the Root Mean Squared Error } \\ \text { GOF } & \text { Goodness of Fit } \\ \text { HDD } & \text { Heating Degree Day } \\ \text { HVAC } & \text { Heating, Ventilation, and Air Conditioning } \\ \text { IMT } & \text { Inverse Modeling Toolkit } \\ \text { MEL } & \text { Miscellaneous Electric Load } \\ \text { R }^{2} & \text { Coefficient of Determination }\end{array}$




\section{Executive Summary}

This project delves into the workflow and results of regression models on monthly and daily utility data (meter readings of electricity consumption), outlining a process for screening and gathering useful results from inverse models. Energy modeling predictions created in Building Energy Optimization software (BEopt ${ }^{\mathrm{TM}}$ ) Version 2.0.0.3 (BEopt 2013) are used to infer causes of differences among similar homes. This simple data analysis is useful for the purposes of targeting audits and maximizing the accuracy of energy savings predictions with minimal costs.

The data for this project are from two adjacent military housing communities of 1,166 houses in the southeastern United States. One community was built in the 1970s, and the other was built in the mid-2000s. Both communities are all electric; the houses in the older community were retrofitted with ground source heat pumps in the early 1990s, and the newer community was built to an early version of ENERGY STAR ${ }^{\circledR}$ with air source heat pumps. The houses in the older community will receive phased retrofits (approximately 10 per month) in the coming years. All houses have had daily electricity metering readings since early 2011.

Inverse modeling provides insight into the actual operational characteristics of the space conditioning systems, the thermal enclosure, and occupant behavior. Variations in the average base load and heating and cooling slopes differed markedly from one community to another. The heating, ventilation, and air conditioning systems in these houses may not be performing as anticipated or may be failing, and thermostat set points may vary widely. Base-load variation indicates a wide range of usage across housing type, size, and occupancy. Schedules (e.g., set points, water use, windows being open, occupants being away on vacation) dramatically impact energy consumption, especially in houses with low heating and cooling requirements where base loads can dominate the whole-building energy consumption.

When normalizing the utility bills of a home, data need to be screened for changes in occupancy and other possible changes in how the building is using energy, such as malfunctioning equipment. Homes with utility data that do not adhere well to generally accepted models could be exhibiting such behavior. Selecting time periods for analysis provided a significant challenge and barrier to an accurate analysis. If a single model were run containing an occupant changeover, the results would be skewed. A model tends to more closely match the data when only one family has been living in the home during the analysis period. Vacation periods also exemplify a type of operational change not represented with simple standard weather normalization procedures and would cause poor model fit. The military communities studied in this project saw rapid turnover of occupants; therefore, without accounting for these changes either by splitting the dataset or leveraging multiyear data, many homes had to be ignored.

Audits represent a large portion of the costs associated with a retrofit program but can provide valuable measurements and observations to help determine the best retrofit strategy. Obtaining submetered and finer-resolution data requires significantly more expense (e.g., performing blower door tests to better understand air infiltration). Acquiring daily energy consumption data requires the installation of new meters on each building, and measuring individual subsystems requires access to the homes and significant costs. Although these detailed data will enable decisions to be made with more certainty, their impact should be weighed against the data acquisition costs. 
Depending on the acceptable level of accuracy, daily data as in this project did not yield significantly different results from monthly data. That is, following basic weather normalization procedures, the daily and monthly results were similar for many of the homes. This report discusses the differences between two resolutions of data, along with limited building characteristic data, to determine how outcomes vary between them.

Consistency is another issue. The methods presented in this report emphasize repeatability through the development of automated techniques. This is important for property management companies and utilities that have large portfolios and are seeking to retrofit all or a subset of them. Reliable and consistent results are needed from any analyses they choose to apply across their portfolios, as discussed in the background literature. The ability to repeat a process and duplicate the results is enhanced through the use of scripting and batch processing in software. Although manual, intuitive techniques yield acceptable results when modeling individual homes, at the larger scale necessary for deep market transformation, the techniques must be consistent and optimized. Leveraging computation is the best way to do this.

Scripted modeling is an important emerging practice used by architects and engineers to analyze energy consumption at the community scale. BEopt Version 2 (BEopt 2013) recently was reworked to implement batch processing capabilities. This allows for the creation of batch processing algorithms within a freely available and simple-to-use energy modeling software. Automation will lower analysis costs and will allow for the application of energy simulations to a much larger portfolio.

This project explores a dataset at a simple level and describes applications of a utility data normalization. There are far more sophisticated ways to analyze a dataset of dynamic, high resolution data; however, this report focuses on simple processes to create big-picture overviews of building portfolios as an initial step in a community-scale analysis.

The Building America program is positioned to provide guidance to industry for the purpose of adoption of new technologies at a large scale. Efforts such as BEopt and Building Energy Simulation Test for Existing Homes (BESTEST-EX 2013) highlight efforts to standardize the modeling process. 


\section{Introduction}

Typical community-scale energy upgrades require house-by-house modeling and testing to determine strategies that would effectively reduce energy usage. At the scale of this study with more than 1,000 homes, this process can become tedious and expensive. Therefore, to the extent possible, tedious processes were automated using batch calculations with software. Most modeling done for this report is brute force, meaning many models were run that did not correspond to the home in question or its final modeled representation (i.e., many models were created that were not used for analysis or predictions). Although the processes presented in this research are not exactly "tender loving care," modeling every home represents individual attention as well as macroscopic views of the home data. This project uses the Inverse Modeling Toolkit (IMT) (Kissock et al. 2002) to study change-point inverse (regression) modeling of utility billing data on a large scale in an effort to reduce the time needed to design and analyze retrofit programs.

Additional data can help with model uncertainty; however, data acquisition costs can add up. The installation of higher resolution meters, for example, needs to be justified by some guarantee there will be better decision-making ability or a beneficial outcome. Physical audits, with the time involved, cost a lot of money. Simply obtaining the data and analyzing the significance is a huge cost for building energy retrofit programs.

IBACOS used linear change-point models to screen 1,166 houses in a suburban neighborhood of legacy production-built houses, with some known general characteristics. The project team evaluated the results of regression models using daily and monthly data to determine if significantly different conclusions could be drawn between the daily and monthly data in an effort to determine if higher time resolution data will influence the analysis results.

\subsection{Background}

IBACOS collaborated with a military housing partner to evaluate the opportunities associated with energy retrofits in military housing. A goal of the retrofit program was to conduct audits and energy modeling to evaluate cost-effective energy upgrades. IBACOS conducted a limited number of audits in two military housing communities in the southeastern United States that were slated for a set of energy upgrades, as had been determined by the military housing partner staff prior to IBACOS' involvement in the project. The project partner began phased retrofits on the homes in fall 2013. Upon completion of the retrofits, IBACOS may perform a verification of the energy savings following from the baseline models established through this research.

The data for this project were from two adjacent military communities of 1,166 houses in the southeastern United States. One community consists of ranch-style homes built in the 1970s, and the other consists of duplex homes built in the mid-2000s. Both communities are all electric; the homes in the older community were retrofitted with ground source heat pumps in the early 1990s, and the newer community was built to an early version of ENERGY STAR ${ }^{\circledR}$ with air source heat pumps. The homes in the older community will receive phased retrofits (approximately 10 per month) in the coming years. All homes have had daily electricity meter readings since early 2011 . 
Regression modeling of utility bills historically has been used to evaluate the "actual" energy savings associated with home energy retrofits and to disaggregate utility bills into relative usage for heating, cooling, and base load. Energy simulations (forward models) can be calibrated to the utility data, and savings resulting from energy conservation measures can be estimated. The Building Performance Institute (BPI) provides standardized procedures for qualifying energy savings estimates in homes (ANSI/BPI-2400-S-2012) (BPI 2012). The standard requires practitioners to qualify energy savings estimates with utility data to increase confidence in predictions.

As higher resolution utility data are becoming available, research is needed to determine how a combination of utility bill analysis and energy simulation can be used with a limited (even optimized) number of physical house audits to identify retrofit measures and to reasonably predict energy savings.

This report documents the normalization of the pre-retrofit utility and building characteristic data following Kissock et al. (2002), which is the process referenced by ANSI/BPI-2400-S-2012 (BPI 2012). Kissock's report provides an overview of different types of linear inverse models and their applicability to residential energy consumption. Inverse modeling, or data-driven modeling, is the derivation of a function's coefficients to fit it to a dataset where the statistical degree of error is minimized. A common application is to quantify energy savings while accounting for temperature differences between pre- and post-retrofit periods.

\subsection{Inverse Modeling}

Inverse modeling refers to assigning values to model inputs based on empirical performance data. This is the reverse of simulations, or forward modeling, which predicts the performance given a list of inputs and physics-based equations. In combination, the two modeling methods provide the ability to reduce uncertainty in energy savings predictions made by simulations.

The most common application of inverse modeling to building energy is for weather normalization, referring to the process to account for differences in weather between two use periods for the purpose of measuring savings from energy conservation measures. ASHRAE Guideline 14, Annex D (ASHRAE 2002) provides the methodology for weather normalizing utility data using regressions, as referenced by BPI (2012).

This research used a simple change-point estimation algorithm as employed by the IMT (Kissock et al. 2002) to assess the variance in performance among a collection of homes. A common model for describing seasonal weather-sensitive use of an all-electric home is a five-parameter model (ASHRAE 2009). Equation 1 describes this model as

$$
E=b_{0}+b_{1} \cdot\left(T-b_{2}\right)^{+}+b_{3} \cdot\left(b_{4}-T\right)^{+},
$$

where

$E=$ total energy consumption for measurement interval

$T=$ average temperature for measurement interval

$b_{0}=$ base-load energy consumption 
$b_{1}=$ heating slope, heating energy increase per unit $T$ above $b_{2}$

$b_{2}=$ heating change-point temperature

$b_{3}=$ cooling slope, cooling energy increase per unit $T$ below $b_{4}$

$b_{4}=$ cooling change-point temperature

\subsection{Research Questions}

This project is designed to create a baseline of pre-retrofit information about homes that will be retrofitted during the coming years. These data can be used in the future to compare actual energy consumption of the post-retrofit houses against the pre-retrofit case and the predicted savings associated with those measures as calculated by BEopt (BEopt 2013). The following are the specific research questions related to this phase of the project:

- How can the consumption data of each home be screened to identify changes in occupancy?

- How do inverse modeling results vary between those using daily data and those using monthly data?

- What is the variation in regression models of the heating and cooling energy slopes and change-point temperatures using daily or monthly utility bills when houses in a community are grouped by floor plan, orientation, square footage, and number of occupants?

- How do inverse models of simulated energy use from BEopt compare to inverse models of utility bills?

- What efficiency characteristics and energy upgrade opportunities can be inferred from inverse modeling?

- How do statistical methods compare to more traditional methods of physical energy audits? 


\section{Mathematical and Modeling Methods}

Of note in this research is the resolution of the utility data. What types of differences in results between monthly and daily inputs might be significant? Throughout this project, analyses were performed on daily and monthly utility data resolution to examine how the results differ between the two.

Annual energy consumption data come packed with electricity consumers: mostly computers, water, lights, heat pumps, and more. The Building America House Simulation Protocols (Hendron and Engebrecht 2010) provide simple ranges of miscellaneous electric loads (MELs), envelope, heating, ventilation, and air conditioning (HVAC), and other parameters useful to estimate or represent the energy consumption of a home. BEopt can be used to calculate energy savings estimates through a calibrated simulation process and with utility data must be leveraged to ensure accuracy in those estimates.

Homes can be understood individually, each with unique traits, and as part of a large set. Figure 1 illustrates the daily electricity consumption of a single home relative to the consumption across the community for the corresponding days. This particular home's daily consumption-the red diamonds - floats in and out of the inner quartile range, as represented by bold black lines. The faint dashed lines encompass $95 \%$ of consumption observed across all the homes.

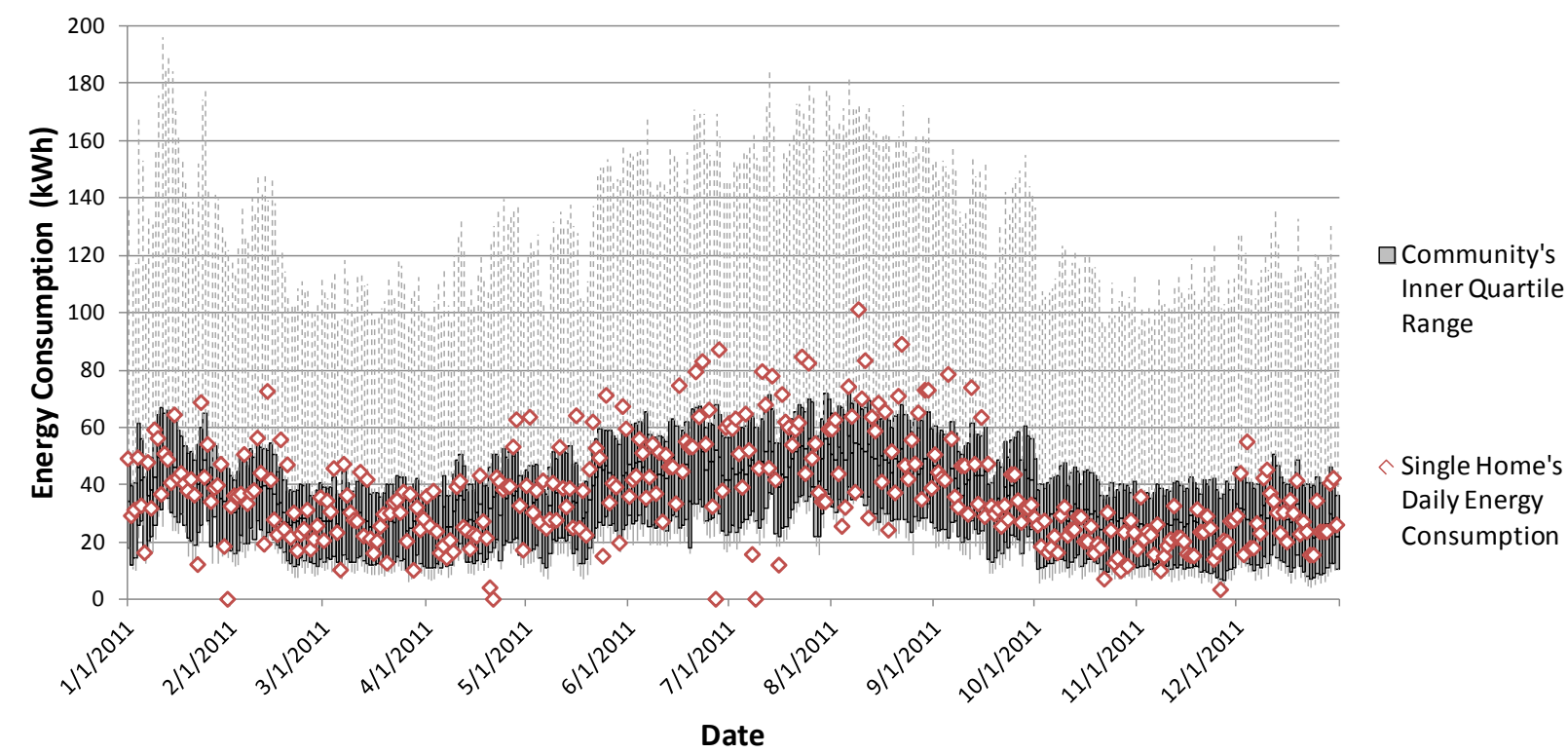

Figure 1. One home's daily electricity consumption overlaying the community's daily energy consumption distribution

Inverse modeling gives clues as to a simple breakdown into the bigger, second-tier parts: heating, cooling, and base load. Smaller loads are more difficult to see, as discussed later in this reportheating is one such small load in this case-and are mostly ignored (difficult to trust) in this and other standard weather normalization processes. Also, by running these inverse models, the quality of the data can be assessed for its appropriate use as a calibration dataset (BPI 2012). 
Casey et al. (2010) performed an analysis of simulated data, asking the question: Can heating slope sorting accurately identify the underperforming homes of a community? They used variable based degree day modeling to sort homes based on a heating performance coefficient determined using a three-parameter linear change-point estimation algorithm. The process correctly sorted homes by performance of simulated utility data with added random noise. The algorithms employed by Casey's team to disaggregate the simulated utility data were similar to the change-point estimation algorithm used by the IMT. This study aims to perform a sorting operation to explore the range of savings potential and to look for clues to the possible causes of abnormal energy consumption.

Occupancy schedules have a significant impact on model results; therefore, the dataset for each home had to be split at apparent shifts in occupant behavior, resulting in periods of low use but not necessarily below an arbitrary threshold. Examples of shifts include a new family moving into a home and vacations. Shifts occur at unique times and frequency unless a mass event occurred. Various techniques were attempted to automatically split, including splitting at temperature, splitting effectively at the shoulder seasons, and running models on distinct periods.

Eger and Kissock (2007) used sliding regressions to look at normalized annual consumption over multiple years to track consumption of an industrial facility over time. By iterating over equalsized intervals (an interval being one year of monthly utility data with corresponding weather) and over multiple years, the report quantified the changing energy use profile of the facility. This report documents an approach based on this work to identify the best full-year intervals within a 3 -year dataset to use in analysis and calibrating simulations.

IBACOS used the IMT (Kissock et al. 2002) to perform change-point estimations and linear regression (normalized least squares). The homes in this study are all-electric homes; therefore, IBACOS chose the five-parameter model to represent the data. The IMT was automated using a Python script (Python 2012) to batch process folders of IMT input files. The IMT was used on both the actual utility data and the BEopt modeling results (BEopt 2013) described below to analyze the difference between the two.

Figure 2 illustrates three years of daily electricity measurements for a single example home. It is one of the 1,166 homes in the community that was analyzed using a standard, automated approach. 


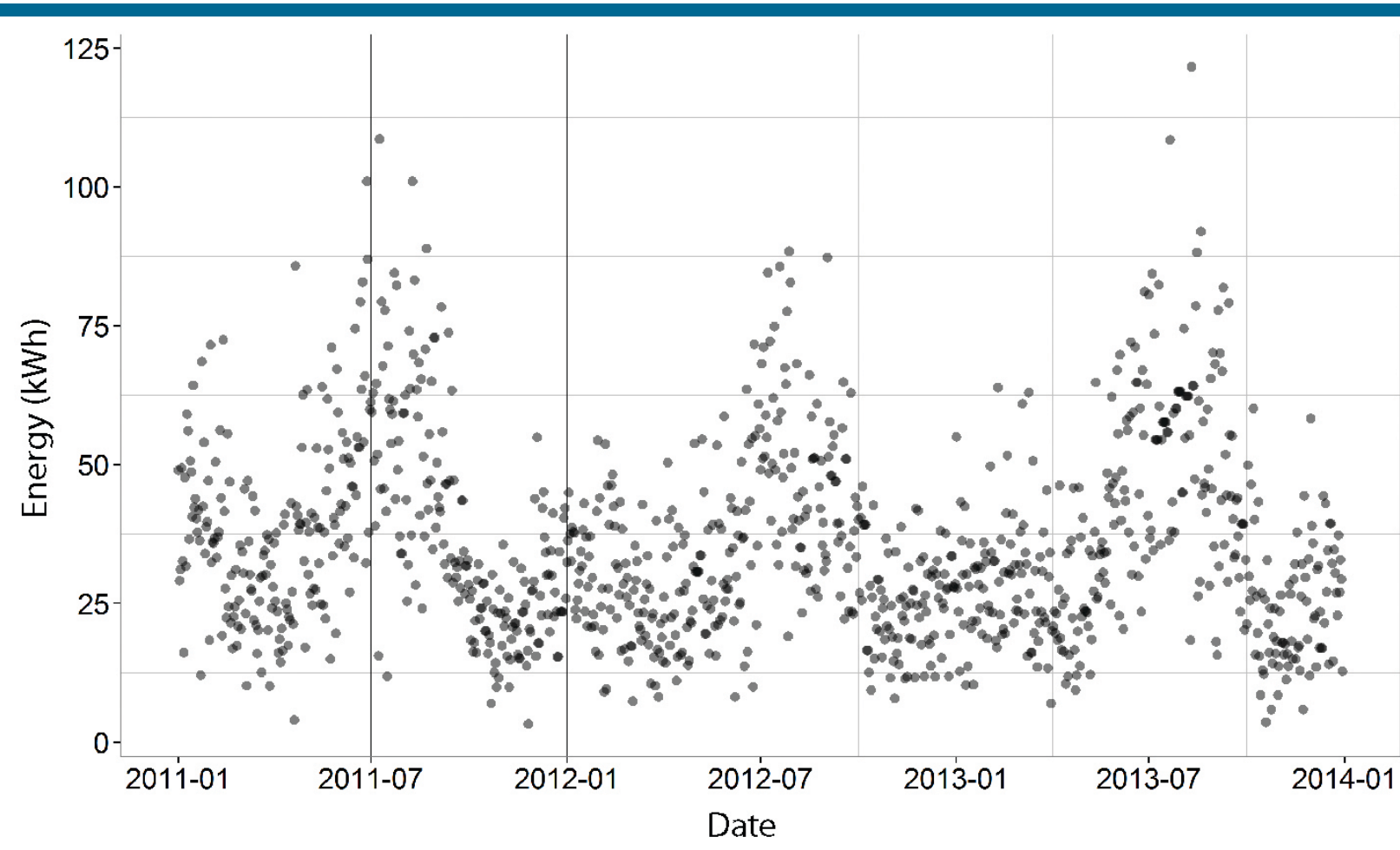

Figure 2. Three years of daily total electricity consumption for one example home

Because the inverse models are simple and linear, dynamic or changing behaviors in the input data can cause them to fail. For the inverse models to align well, they must have 1 full year of data with more or less consistent set points, miscellaneous loads, and other occupant-influenced drivers of electricity consumption. The shifts can be permanent, as when occupants move in or out of a home, or temporary, as when occupants go on vacation. Whether permanent or temporary, these shifts will cause models to fail if contained in the utility data fed into the models.

Figure 3 illustrates a house with one behavior at the beginning of the 3 -year interval, a period with no consumption in the house (which is assumed to be a transition period in which the home was unnoccupied), and what appear to be new occupants of the house at the end of the interval. Conditions with uniform occupancy will result in better model alignment.

Again, Figure 3 illustrates an example home with three apparent intervals: two operational periods interrupted by an "away" period. This home would have been thrown out because it exceeded the goodness-of-fit (GOF) thresholds without splitting the dataset into three and running each set as separate models. Doing so automatically to batch process all homes in the dataset represented a significant challenge. The following section describes a method for leveraging multiyear data to throw out intervals with presumably a change in occupants or vacation periods. 


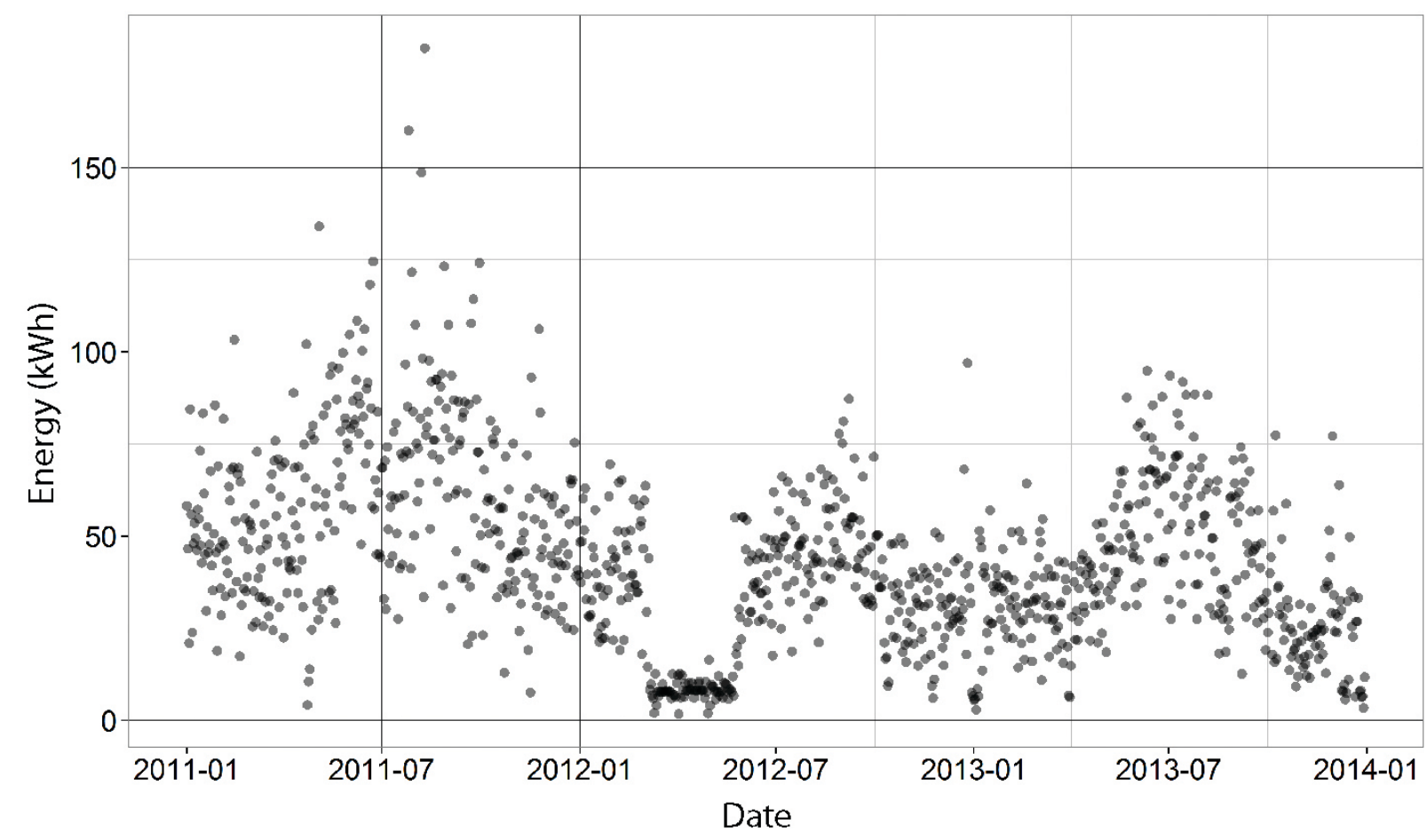

Figure 3. Total daily electricity consumption with interruption for one example home

\subsection{Sliding Regressions}

The following section describes the method for extracting reliable models for each home in the community using sliding regressions. A sliding regression is performed by modeling every oneyear interval within the dataset, shifting the interval by one step for each successive model run. Sequential intervals differ by 1 week for daily utility data and 1 month for monthly utility data, dropping the first point of the previous interval and adding the next sequential point to the end. Figure 4 shows, for example, how the monthly intervals were taken from the full 3 years.

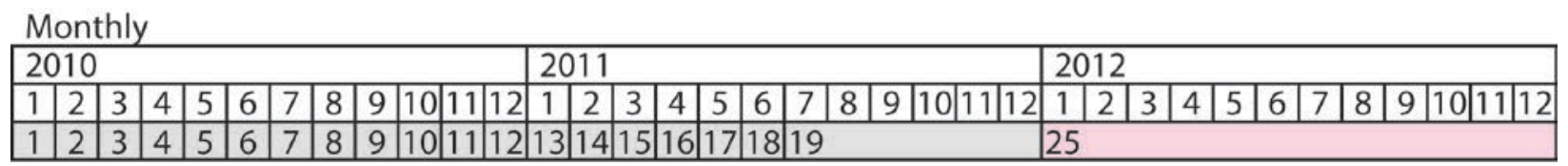

Figure 4. Monthly graphic representation of sliding regression intervals

For daily input data and with a 1-week separation between intervals, the result is 105 $(52 \times 2+1)$ individual models with sequential start and end dates. For monthly data, with 1 month separating each interval, the result is 24 models. Changes cause the parameters to adjust to account for the differences between the days or months. Notice the change points are on a grid, as controlled in the algorithms of the IMT. Figure 5 shows side-by-side sliding regression results for the example home from Figure 3. There is one point in each plot cell for each year interval modeled for the one house. Only the coefficient of determination $\left(R^{2}\right)$ is depicted for the sake of simplicity in the graphic, whereas the coefficient of variance of the root mean squared error (CV-RMSE) also was used to filter homes. 

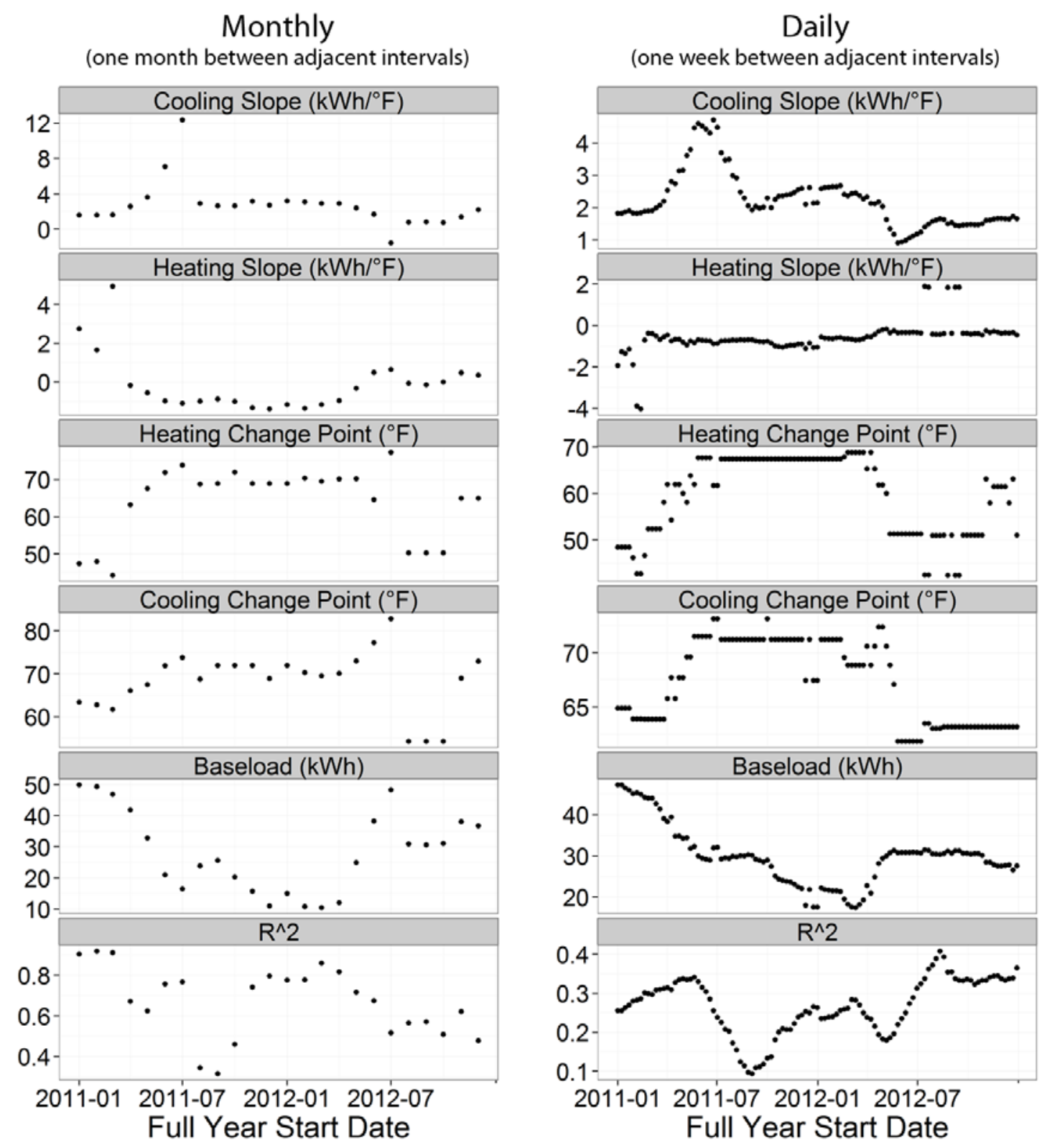

Figure 5. Example sliding regression results for a single home

Splitting the dataset in an automated fashion represented a significant technical challenge for the research team. The task was to identify when occupants moved out of the home and/or occupants moved into the home. Vacation periods or intentional behavioral changes such as the adjustment of a thermostat will have an impact as well but not as dramatic as if a completely new family moves into a home. If there is no change in occupancy, the models will show better alignment with the data. This splitting is simple to do visually; however, to batch process all homes, the team developed a script to perform the splitting automatically and to return the models for any one-year interval for each home that passed all fitness criteria. To achieve the splits, the team employed sliding regression to throw out data points with poor GOF. 


\subsection{Goodness-of-Fit Thresholds}

To assess the model's representation of the data, GOF measures were used to assess the model's fit for each 1-year interval. The first test of model fitness used in this analysis was the $\mathrm{R}^{2}$, a measure commonly used as the sole fitness criteria in weather normalization. It represents the ability of the model to predict individual observed data points. A value of 1 represents a perfect match where every observation falls exactly on the model, with lower values having lower fitness. A second commonly used measure is the CV-RMSE. It is a percentage value and corresponds to the standard deviation of the model fit. Lower values of CV-RMSE indicate good fit, inversely to $\mathrm{R}^{2}$.

Arbitrary thresholds were established to sort the models into those with good fit and those with bad fit. The fitness threshold values were dependent on the data input to the model. Statistical measures must be given a fitness threshold for acceptance of model validity. Reddy and Maor (2006), for example, placed a CV-RMSE threshold of $20 \%$ for calibrated simulations. These thresholds also can take into account the climate of the homes. In the case of this study, the heating loads were very low, and their contribution was buried in the noise, so to speak. In warm climates, one would expect models to more closely align to the data if winter months are excluded from those models. Sub-year models, or models with fewer than the full number of days or months, were not run as part of this study but will be attempted in future research.

The BPI (2012) standard considers only monthly utility data, establishing a CV-RMSE of 20\% as a threshold. Therefore, observations of the results were used to determine new thresholds for the models with daily input. Intuitively, the values seemed to work. Table 1 documents the statistical GOF measures used to filter data. Results with counterintuitive slopes also were thrown out. A counterintuitive slope is, for example, a positive heating slope, which implies heating usage would go up with higher outdoor temperatures. A counterintuitive cooling slope is a negative cooling slope.

Table 1. GOF Threshold Values per Data Resolution

\begin{tabular}{c|c|c}
\hline Utility Bill Interval & \multicolumn{2}{|c}{ GOF Measure } \\
\hline & $\mathbf{R}^{2} \geq$ & $\mathbf{C V}-\mathrm{RMSE} \leq$ \\
\hline Monthly & 0.7 & $20 \%$ \\
Daily & 0.25 & $40 \%$ \\
\hline
\end{tabular}

Whenever an individual model from a sliding regression passed all of the GOF criteria, its results for each continuous interval were analyzed. A continuous interval is a sequence of models with uninterrupted GOF passing values. Consider, for example, the results shown in Figure 6 . This figure is the same as the previous plot with green regions shaded, indicating all points that pass the GOF measures documented in Figure 5. Homes with positive heating slopes and negative cooling slopes also were not passed. 


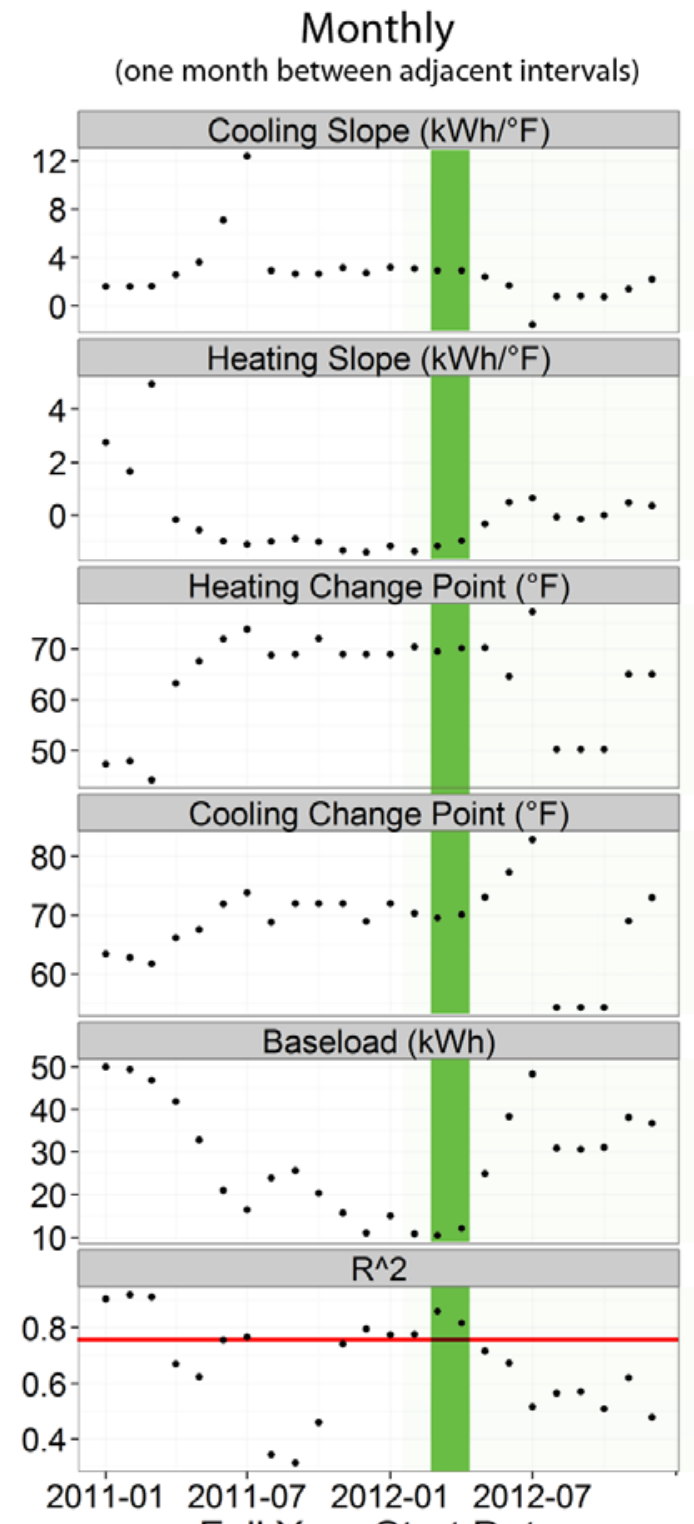

Full Year Start Date
Daily

(one week between adjacent intervals)

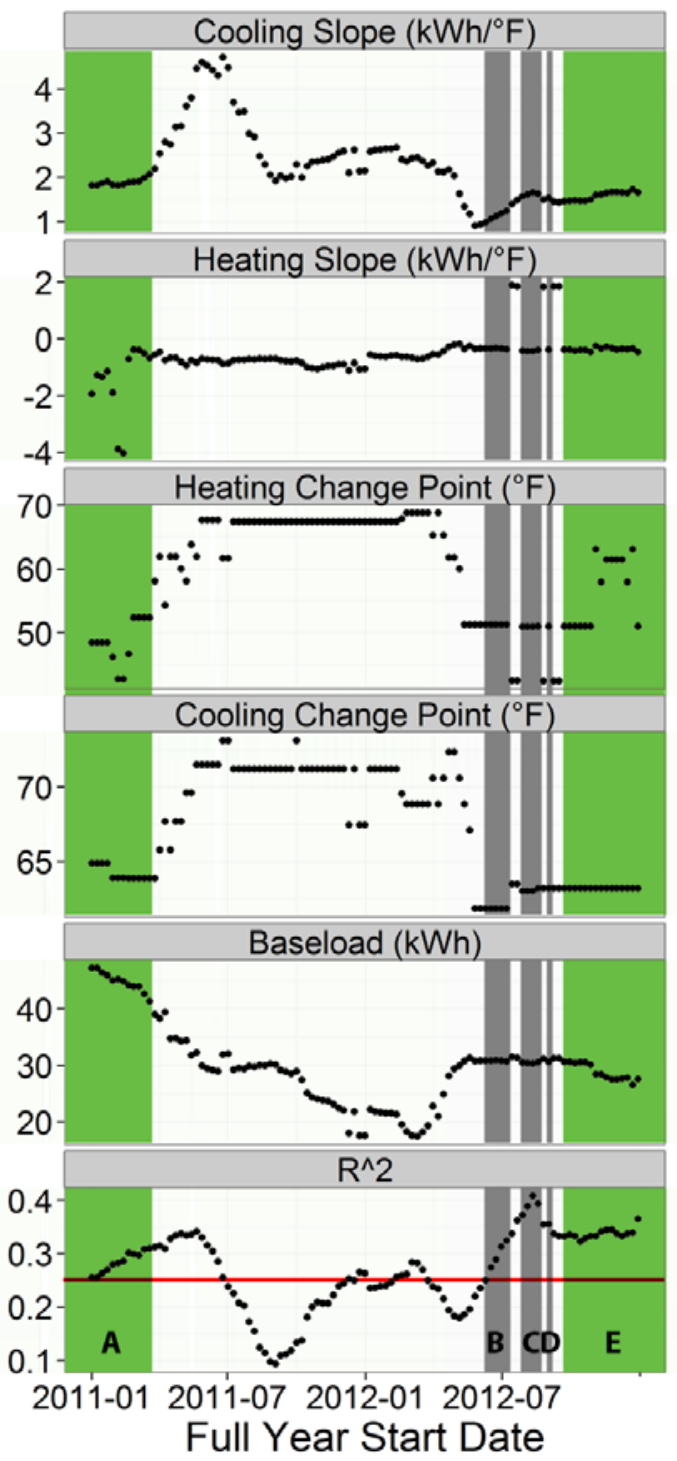

Figure 6. Example sliding regression results with shaded "passing" time intervals

In the daily results, there were five sets of sequential periods, two of which had more than 10 sequential well-fit models. The other sets with only a few models can be thrown out. Those two intervals with sufficient numbers of observations can be used to obtain two distinct results for a single house, further isolating the effects of the structure rather than those of the occupants or weather.

For this particular home, there were distinct differences between the monthly and daily results. Table 2 shows the results for each of the green shaded regions in Figure 6. The letters for the multiple daily intervals, A through E, are indicated on Figure 6. Daily intervals B through D are grayed out in Figure 6 because the number of samples was few, and the result of $\mathrm{E}$ had 
15 samples. The daily filter found two clusters of models with passing numbers, whereas the monthly filter found only one.

Table 2. Summary of Sliding Regression Results With Passing GOF Measures, Monthly and Daily

\begin{tabular}{|c|c|c|c|c|c|c|c|c|}
\hline \multirow[b]{2}{*}{ Interval } & \multirow[b]{2}{*}{ Measure } & \multicolumn{2}{|c|}{$\begin{array}{c}\text { Slopes } \\
\left(k W h / C D D^{a}\right)\end{array}$} & \multicolumn{2}{|c|}{$\begin{array}{c}\text { Balance Point } \\
\text { Temperatures }\left({ }^{0} \mathrm{~F}\right)\end{array}$} & \multirow{2}{*}{$\begin{array}{l}\text { Base Load } \\
\text { (kWh/day) }\end{array}$} & \multicolumn{2}{|l|}{ GOF } \\
\hline & & Cooling & Heating & Heating & Cooling & & CV-RMSE & $\mathbf{R}^{2}$ \\
\hline \multirow{3}{*}{ Monthly } & Mean & 2.66 & 0.75 & 69.87 & 71.28 & 17.68 & 17.43 & 0.79 \\
\hline & Samples & 2 & 2 & 2 & 2 & 2 & 2 & 2 \\
\hline & $\begin{array}{c}\text { Confidence } \\
(95 \%)\end{array}$ & 0.49 & 0.81 & 0.70 & 3.45 & 14.18 & 1.43 & 0.14 \\
\hline \multirow{3}{*}{ Daily A } & Mean & 1.89 & 1.52 & 48.48 & 64.21 & 44.87 & 37.24 & 0.28 \\
\hline & Samples & 12 & 12 & 12 & 12 & 12 & 12 & 12 \\
\hline & $\begin{array}{c}\text { Confidence } \\
(95 \%)\end{array}$ & 0.05 & 0.80 & 2.23 & 0.32 & 1.12 & 0.53 & 0.01 \\
\hline \multirow{3}{*}{ Daily B } & Mean & 1.12 & 0.34 & 51.29 & 61.82 & 30.84 & 34.90 & 0.29 \\
\hline & Samples & 5 & 5 & 5 & 5 & 5 & 5 & 5 \\
\hline & $\begin{array}{c}\text { Confidence } \\
(95 \%)\end{array}$ & 0.13 & 0.02 & 0.00 & 0.00 & 0.11 & 0.30 & 0.04 \\
\hline \multirow{3}{*}{ Daily C } & Mean & 1.62 & 0.42 & 51.02 & 63.05 & 30.45 & 34.78 & 0.39 \\
\hline & Samples & 4 & 4 & 4 & 4 & 4 & 4 & 4 \\
\hline & $\begin{array}{c}\text { Confidence } \\
(95 \%)\end{array}$ & 0.06 & 0.03 & 0.06 & 0.12 & 0.16 & 0.60 & 0.02 \\
\hline \multirow{3}{*}{ Daily D } & Mean & 1.54 & 0.38 & 51.08 & 63.16 & 30.66 & 36.39 & 0.36 \\
\hline & Samples & 1 & 1 & 1 & 1 & 1 & 1 & 1 \\
\hline & $\begin{array}{c}\text { Confidence } \\
(95 \%)\end{array}$ & $\mathrm{NA}^{\mathrm{b}}$ & NA & NA & NA & NA & NA & NA \\
\hline \multirow{3}{*}{ Daily E } & Mean & 1.59 & 0.37 & 56.37 & 63.16 & 28.83 & 38.29 & 0.34 \\
\hline & Samples & 15 & 15 & 15 & 15 & 15 & 15 & 15 \\
\hline & $\begin{array}{c}\text { Confidence } \\
(95 \%)\end{array}$ & 0.05 & 0.03 & 2.94 & 0.00 & 0.82 & 0.52 & 0.01 \\
\hline
\end{tabular}

${ }^{a}$ Cooling degree day.

${ }^{\mathrm{b}}$ Not applicable.

The monthly results, although statistically valid according to the thresholds, show the energy profile for an unoccupied period. Perhaps models of monthly data are more prone to this error because the sample size is small. The monthly results are sensitive to the heating slope GOF criteria, and the first three intervals were thrown out because of that threshold. Because this climate zone has a low heating load, the heating slope was not used to screen homes. Table 3 documents the results with this modification in GOF application. Ignoring the heating slope value for filtering purposes but not for output purposes, the monthly result added an additional passing date range; in the daily results, B through E merged into one. 
Table 3. Final Results for Example Home, Monthly and Daily

\begin{tabular}{|c|c|c|c|c|c|c|c|c|}
\hline \multirow[b]{2}{*}{ Interval } & \multirow[b]{2}{*}{ Measure } & \multicolumn{2}{|c|}{$\begin{array}{c}\text { Slopes } \\
(\mathrm{kWh} / \mathrm{CDD})\end{array}$} & \multicolumn{2}{|c|}{$\begin{array}{c}\text { Balance Point } \\
\text { Temperatures }\left({ }^{0} \mathrm{~F}\right)\end{array}$} & \multirow{2}{*}{$\begin{array}{l}\text { Base Load } \\
\text { (kWh/day) }\end{array}$} & \multicolumn{2}{|l|}{ GOF } \\
\hline & & Cooling & Heating & Heating & Cooling & & CV-RMSE & $\mathbf{R}^{2}$ \\
\hline \multirow{3}{*}{ Monthly A } & Mean & 1.62 & -* & 46.51 & 62.63 & 48.70 & 7.99 & 0.91 \\
\hline & Samples & 3 & 3 & 3 & 3 & 3 & 3 & 3 \\
\hline & $\begin{array}{c}\text { Confidence } \\
(95 \%)\end{array}$ & 0.03 & - & 2.24 & 0.95 & 1.81 & 0.54 & 0.01 \\
\hline \multirow{3}{*}{ Monthly B } & Mean & 2.66 & 0.75 & 69.87 & 71.28 & 17.68 & 17.43 & 0.79 \\
\hline & Samples & 2 & 2 & 2 & 2 & 2 & 2 & 2 \\
\hline & $\begin{array}{c}\text { Confidence } \\
(95 \%)\end{array}$ & 0.49 & 0.81 & 0.70 & 3.45 & 14.18 & 1.43 & 0.14 \\
\hline \multirow{3}{*}{ Daily A } & Mean & 1.89 & 1.52 & 48.48 & 64.21 & 44.87 & 37.24 & 0.28 \\
\hline & Samples & 12 & 12 & 12 & 12 & 12 & 12 & 12 \\
\hline & $\begin{array}{c}\text { Confidence } \\
(95 \%)\end{array}$ & 0.04 & 0.71 & 1.99 & 0.28 & 0.99 & 0.47 & 0.01 \\
\hline \multirow{3}{*}{ Daily B } & Mean & 1.50 & 0.37 & 54.29 & 62.88 & 29.56 & 36.98 & 0.34 \\
\hline & Samples & 25 & 25 & 25 & 25 & 25 & 25 & 25 \\
\hline & $\begin{array}{c}\text { Confidence } \\
(95 \%)\end{array}$ & 0.08 & 0.02 & 1.89 & 0.21 & 0.57 & 0.72 & 0.01 \\
\hline
\end{tabular}

* Heating slope was not valid and was ignored.

Note that there is very little change among the cooling parameters but a roughly $35 \%$ decrease in base-load consumption. The heating parameters also shifted to be less efficient, possibly caused by the shift in base load, which, in theory, provided heat to the conditioned space, lessening the amount of heat necessary from the HVAC system. However, there is a high level of uncertainty in the heating data because of the warm climate.

Table 3 compares daily estimates to monthly estimates. The reported values are those used ultimately to sort the homes in terms of their performance. This process ensures that the most accurate electricity measurement periods are chosen for analysis and that homes with no valid models are excluded. The example analysis for a single home was batch applied to each home in the dataset and then used to sort homes.

The best model was not the only model used because, in most cases, many others were acceptable for any given home, and the best model could be an outlier of passing models. For the example home, there were two distinct passing intervals, with a significant shift in base load between the two periods (from $45 \mathrm{kWh}$ to $30 \mathrm{kWh}$, a decrease of $33 \%$ ). Therefore, all passing models are useful for analysis, and each home received a range of base load in time rather than single values, representing all valid models.

\subsection{Interpreting Inverse Modeling Toolkit Results}

Figure 7 contains a data sample of full-year data from four representative homes and their IMT five-parameter results overlaid as a line, including monthly and daily resolutions. These example homes appear to have normal or continuous operation; therefore, the statistics show fair 
agreement with the model. The upper right home is a high base-load and high slope home. The lower left home is a low base-load and low slope home. Note that the monthly and daily results closely align in these "normal" homes.

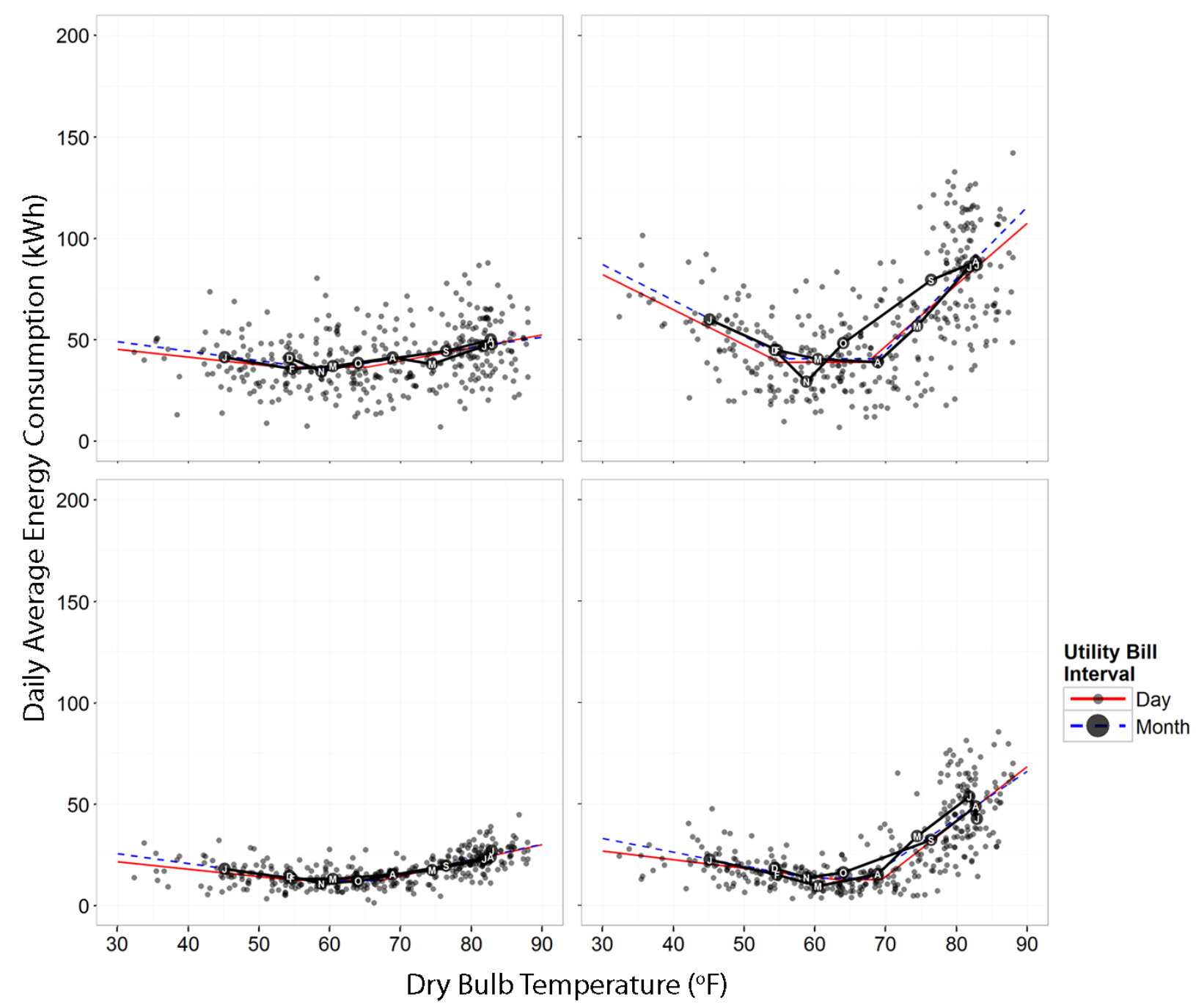

Figure 7. One full year of results for four example homes, low and high energy consumption

Once models with good fit were established for each address possible, the team performed some tests to get a sense of how the IMT results were driven. For example, what might the effect of a reduced-capacity ground source heat pump look like through the lens of the IMT?

The research team used BEopt to perform some simple simulations of the homes with varying degrees of performance. Simulations were useful to test the relationship between known changes in model inputs and how the IMT registers those changes in terms of its model coefficients.

This sensitivity analysis gives a sense to the response of the IMT to known building and operational effects. 
Table 4 documents the BEopt input parameters and their values. Note that the set point inputs were paired; not all combinations of cooling and heating set points presented were made. The baseline model inputs are in boldface type and in the leftmost values column. Simulations were run with the inputs listed, and the hourly results were totaled for each day and were averaged per month. The daily and monthly results were modeled in the IMT using the five-parameter model used on the measured data.

Figure 8 shows the results of the simulation runs. Dark-green plot facets are IMT parameters that saw significant change with variation in the BEopt input on the vertical axis. Light-green shaded cells are those with minor effects. These effects are considered specific to this dataset. Other climates and building types would have different sensitivities. The input geometry matches the homes in the dataset, and the weather is the same. Climate affects the magnitude of change induced by any one parameter. For example, air infiltration in this instance is not having a noticeable effect on home performance; however, in a colder climate, one would expect the input to have a noticeable impact on heating loads. Equipment efficiency and size parameters were adjusted in parallel because the team assumed the coefficient of performance (COP) is closely tied to the capacity of the equipment. 
Table 4. BEopt Input Parameters and Baseline Values

\begin{tabular}{|c|c|c|c|c|c|c|c|c|c|c|c|c|c|}
\hline & Set Point Mode & 0 & 1 & 2 & 3 & 4 & 5 & 6 & 7 & 8 & 9 & 10 & 11 \\
\hline \multirow{2}{*}{ Set Points $\left({ }^{\circ} \mathbf{F}\right)$} & Heating & 71 & 72 & 68 & 64 & 60 & 56 & 56 & 56 & 56 & 68 & 64 & 60 \\
\hline & Cooling & 76 & 72 & 76 & 76 & 76 & 76 & 72 & 68 & 64 & 72 & 72 & 72 \\
\hline \multirow{4}{*}{$\begin{array}{l}\text { Equipment Size } \\
\text { and Efficiency }\end{array}$} & Size (MBtu/h) & 24 & & & & & & & & & & & \\
\hline & Size (tons) & 2 & & & & & & & & & & & \\
\hline & $\mathrm{COP}$ & 4 & 3.6 & 3.2 & 2.8 & 2.4 & 2 & 1.6 & 1.2 & 0.8 & 0.4 & 0 & \\
\hline & $\begin{array}{c}\text { Energy efficiency } \\
\text { ratio }(B t u / h / W)\end{array}$ & 21.2 & 19.1 & 17.0 & 14.8 & 12.7 & 10.6 & 8.5 & 6.4 & 4.2 & 2.1 & 0.0 & \\
\hline Air Infiltration & ACH50 & 15 & 17 & 13 & 11 & 9 & 7 & & & & & & \\
\hline \multirow[t]{2}{*}{ Ducts } & Leakage $(\%)$ & 21 & 39 & 36 & 33 & 30 & 27 & 24 & 16 & 11 & 6 & 1 & \\
\hline & Insulation R-value & 6 & 0 & 4 & 8 & & & & & & & & \\
\hline \multirow[t]{2}{*}{ Base Load } & $\begin{array}{l}\text { loads } \\
\text { loder }\end{array}$ & 1.0 & 2.00 & 0.50 & & & & & & & & & \\
\hline & Other electric loads & 1.0 & 4.00 & 2.00 & 1.50 & 0.75 & 0.50 & 0.25 & & & & & \\
\hline
\end{tabular}

ACH50 is air changes per hour at 50 Pascals. 


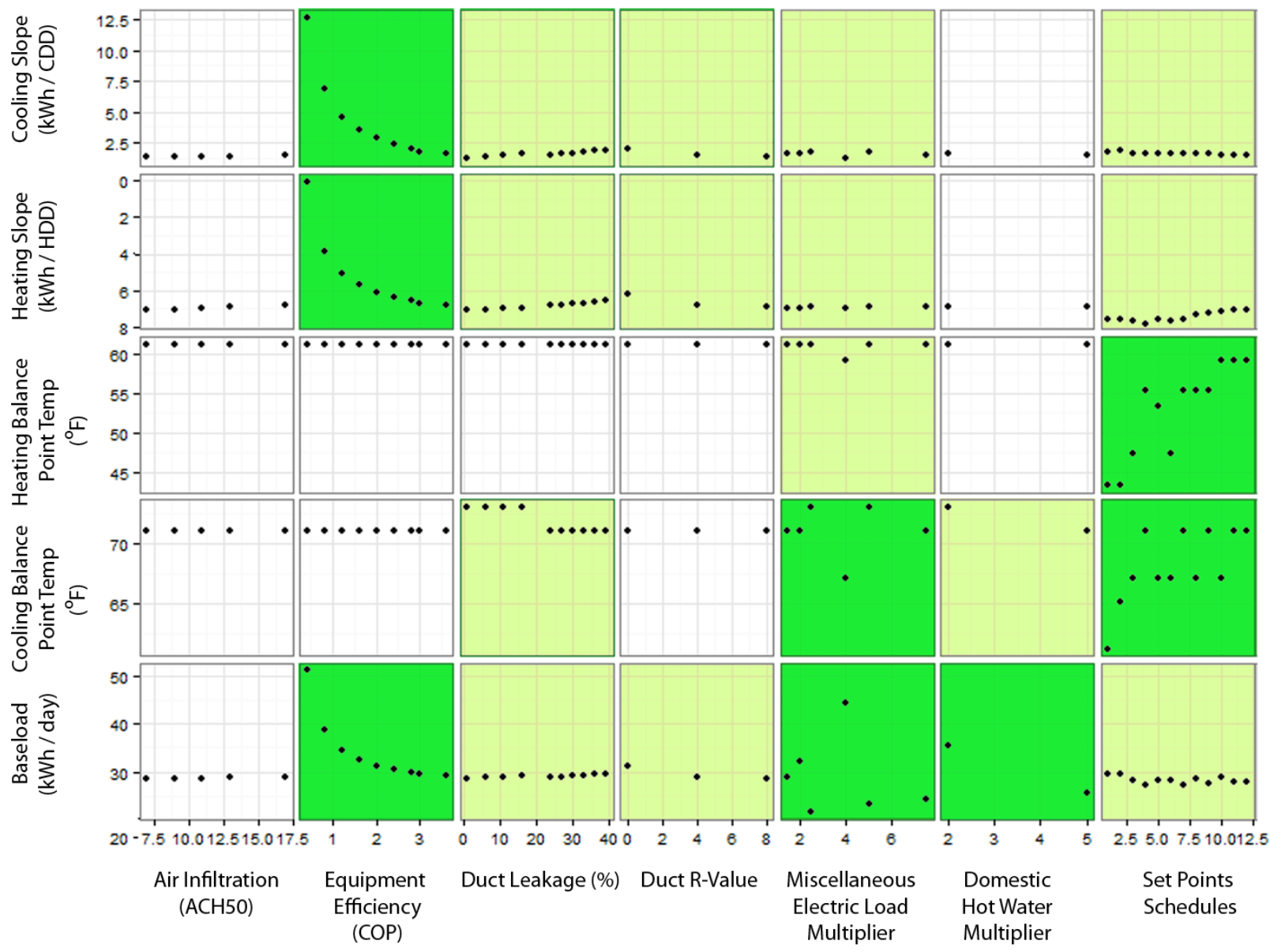

Figure 8. BEopt to IMT sensitivity analysis results. (HDD is heating degree day.)

Slopes are affected primarily by the equipment efficiency, and a significant decrease in the performance of the HVAC equipment should register as an increased heating or cooling slope. Balance point temperature is observed to change primarily with set point inputs. Occupant comfort is a driving force behind balance point temperatures. Because this community has very little variation in the building enclosure, which also affects balance points, the effect is expected to be caused primarily by thermostat set point temperatures. Base loads also can cause balance points to change because of the heat generated by appliances and humans. Inefficient appliances emitting heat will meet part of the heating load and add to the cooling load, impacting the estimated coefficients.

Table 5 summarizes the assumptions derived from the BEopt models.

The research team ran a different set of BEopt models to get a sense of how a larger range of possible BEopt input combinations based on the static building information would align with the utility bills. The team ran both datasets — the simulated and the actual — through the IMT and then compared the inlier results. 
Table 5. Implications of Five Parameters Derived From BEopt Simulations

\begin{tabular}{|c|c|c|}
\hline IMT Result & Real Implication & Potential Upgrade Opportunities \\
\hline $\begin{array}{l}\text { Steep Cooling } \\
\text { Slope }\end{array}$ & $\begin{array}{l}\text { House uses much more } \\
\text { energy as the outdoor } \\
\text { temperature rises }\end{array}$ & $\begin{array}{l}\text { Building enclosure inefficient; duct } \\
\text { leakage; inefficient/failing air conditioning } \\
\text { unit or air conditioning unit improperly } \\
\text { commissioned }\end{array}$ \\
\hline $\begin{array}{l}\text { Steep Heating } \\
\text { Slope }\end{array}$ & $\begin{array}{l}\text { House uses much more } \\
\text { energy as the outdoor } \\
\text { temperature drops }\end{array}$ & $\begin{array}{l}\text { Building enclosure inefficient; duct } \\
\text { leakage; inefficient/failing heating unit } \\
\text { (e.g., furnace, heat pump) or improper } \\
\text { commissioning of the heating unit }\end{array}$ \\
\hline $\begin{array}{c}\text { Cooling } \\
\text { Change Point }\end{array}$ & $\begin{array}{l}\text { Outdoor temperature at } \\
\text { which cooling is used in the } \\
\text { house }\end{array}$ & $\begin{array}{l}\text { Indication of relative efficiency of the } \\
\text { building enclosure and the indoor } \\
\text { thermostat set point }\end{array}$ \\
\hline $\begin{array}{c}\text { Heating } \\
\text { Change Point }\end{array}$ & $\begin{array}{l}\text { Outdoor temperature at } \\
\text { which the house needs } \\
\text { heating }\end{array}$ & $\begin{array}{l}\text { Indication of relative efficiency of the } \\
\text { building enclosure and the indoor } \\
\text { thermostat set point }\end{array}$ \\
\hline Base Load & $\begin{array}{l}\text { Relative energy use } \\
\text { independent of weather }\end{array}$ & $\begin{array}{l}\text { Indication of occupant lifestyle; } \\
\text { miscellaneous plug loads; may be an } \\
\text { indicator of high domestic hot water } \\
\text { consumption }\end{array}$ \\
\hline
\end{tabular}

Each ranch house plan type was input into BEopt Version 2.0.0.3 (BEopt 2013), including the building characteristics that were collected during the limited number of on-site audits. Each building plan's window areas, aspect ratio, envelope area, and overhangs were reasonably consistent from house to house. Only unique combinations of orientation and building plan were modeled.

Table 6 details the parameters that were changed and the values used for the parametric analysis. In all, there were 17 building plan types, some with minor variations, and each at one of 8 orientations, making 91 unique combinations (baseline models) of orientation and building plan.

With each parameter change, 3,264 results were generated -24 models for each unique floor plan and orientation (17 plans and 8 orientations). Floor plans and orientations were matched with each home in the utility bill dataset, and of the 24 variations, the model with the best statistical fit was selected as representative of the home. 
Table 6. Parameters Changed for BEopt Modeling

\begin{tabular}{c|c}
\hline Category & Values \\
\hline $\begin{array}{c}\text { Cooling Set Point Temperature } \\
\text { (Weekday-Weekend) }\end{array}$ & 71,76 \\
\hline $\begin{array}{c}\text { Heating Set Point Temperature } \\
\text { (Weekday-Weekend) } \\
\text { MELs }\end{array}$ & 68,71 \\
Simulation Engine & $0.5,1.0,1.5$ \\
Infiltration (ACH50) & EnergyPlus (EnergyPlus 2013) \\
Natural Ventilation & 7,10 \\
Relative Humidity Set Point & BEopt default \\
HVAC Equipment Sizing & Default \\
Dehumidification & BEopt default \\
Ducts (Leakage, R-Value) & None \\
\hline
\end{tabular}




\section{Results}

Data screening is the process of sorting between model results that can be trusted and those that should be "kept at arm's length during important meetings." The research team performed additional sorting on square footage, geometry, year built, and number of occupants.

With only 1 year of data, further work could be done to run sub-years using the daily data. There is an advantage with the daily data to selectively remove outlier points. Monthly data may remove only a few data points before the home's data are not viable. The team wanted to test the sensitivity of the results to the number of input homes. It was thought that uncertainty would decrease as more years were included in the analysis, making the case for acquiring multiple years of data.

\subsection{Data Screening Results}

Table 7 summarizes the screening results, broken out by individual measure, both for daily and monthly input data. The survival rate is listed for each individual as well as for combined thresholds. With the additional years of data from which to draw, there is significantly higher confidence in the results. The ability to be more selective in which data are input into the model is an advantage to the goal of accuracy.

Table 7. Filtering Iterations, Survival Percentage, and GOF Measures, Daily and Monthly

\begin{tabular}{c|c|c|c}
\hline & $\begin{array}{c}\text { CV-RMSE } \leq \mathbf{2 0} \% \\
\text { Monthly } \\
\text { (45\% Daily) }\end{array}$ & $\begin{array}{c}\mathbf{R}^{2} \geq \mathbf{0 . 7 0} \text { Monthly } \\
\text { (0.25 Daily) }\end{array}$ & Both \\
\hline One Year & $48 \%(62 \%)$ & $36 \%(47 \%)$ & $30 \%(30 \%)$ \\
Three Years & $97 \%(97 \%)$ & $97 \%(89 \%)$ & $93 \%(82 \%)$ \\
\hline
\end{tabular}

Figure 9 illustrates pre- and post-screening GOF measures. Each blue dot is the best model for a home's data from the sliding regression model runs. The red dots show a single unfiltered random year and its noisy results. Any individual year will pass a small percentage of homes. Those homes that did not pass all the GOF measures in the filtered results appear at zero on the y-axis. 

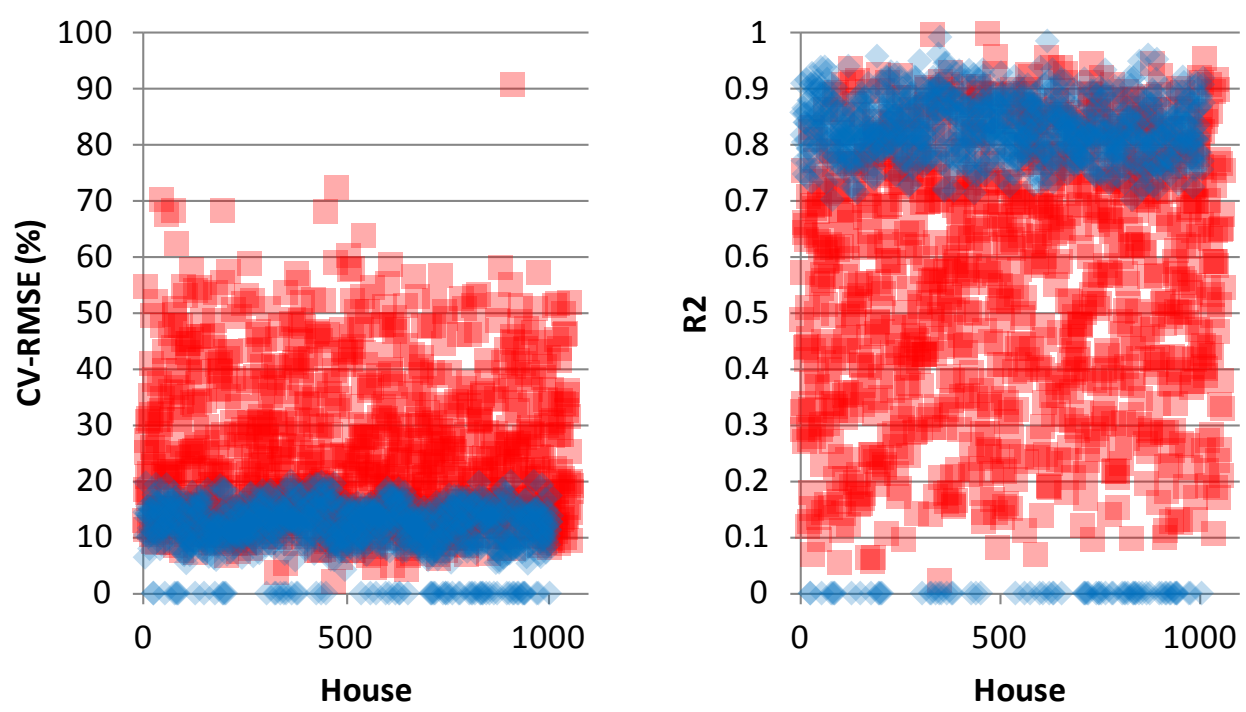

Monthly 1 yr

Monthly 3 yr

Figure 9. GOF measures for unscreened 1-year and 3-year screened averages

Figure 10 shows the averaged results. Each home's models with acceptable GOF values are averaged, resulting in a single value. Across homes, the distribution of inverse modeling results for daily and monthly inputs is shown.
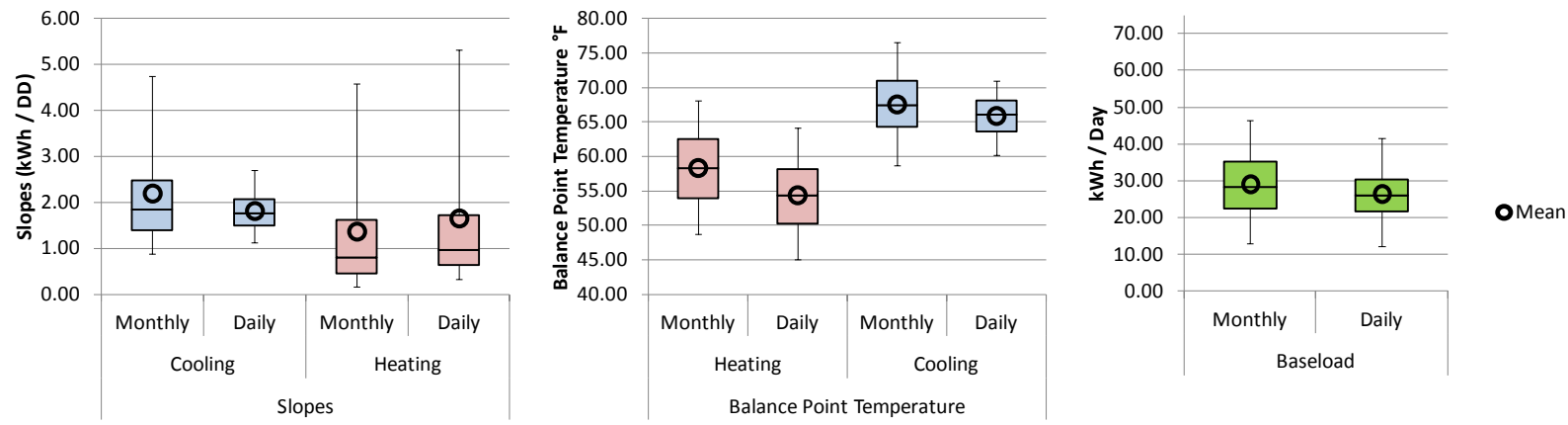

Figure 10. Inverse modeling results

Table 8 summarizes the inverse modeling results for the entire community. Each observation is an individual home's average of all its models passing all GOF criteria. Heating slopes tend to create errors in low-load homes and thus lower passing rates. Some cooling slopes still fail, but because it is a higher magnitude load with clear signals, far fewer failures occur. 
Table 8. Summary of Inverse Modeling Results

\begin{tabular}{|c|c|c|c|c|c|c|c|c|c|c|c|c|}
\hline & \multicolumn{6}{|c|}{$\begin{array}{c}\text { Monthly IMT Results, Inliers } \\
\text { Averaged Results }\end{array}$} & & \multicolumn{5}{|c|}{$\begin{array}{c}\text { Daily IMT Results, Inliers } \\
\text { Averaged Results }\end{array}$} \\
\hline & Z & 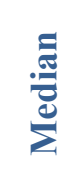 & 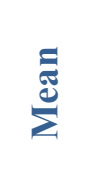 & 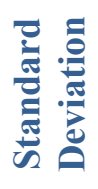 & 葛 & 望总 & Z & 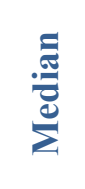 & $\sum^{\tilde{E}}$ & 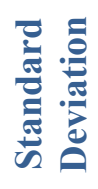 & i气 & 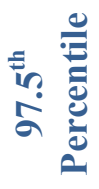 \\
\hline $\begin{array}{c}\text { Heating } \\
\text { Slope } \\
\text { (kWh/HDD) }\end{array}$ & $860 *$ & 0.8 & 1.4 & 1.7 & 5.9 & 0.1 & 820 & 1.0 & 1.7 & 2.2 & 7.4 & -0.3 \\
\hline $\begin{array}{c}\text { Cooling } \\
\text { Slope } \\
(\mathbf{k W h} / \mathrm{CDD})\end{array}$ & 929 & 1.8 & 2.2 & 1.5 & 0.8 & 6.3 & 804 & 1.8 & 1.8 & 0.5 & 1.0 & 2.9 \\
\hline $\begin{array}{c}\text { Heating } \\
\text { Change } \\
\left.\text { Point ( }{ }^{\circ} \mathbf{F}\right)\end{array}$ & 937 & 58.2 & 58.4 & 6.0 & 46.9 & 69.7 & 823 & 54.3 & 54.4 & 5.9 & 43.4 & 66.6 \\
\hline $\begin{array}{c}\text { Cooling } \\
\text { Change } \\
\text { Point }\left({ }^{\circ} \mathrm{F}\right)\end{array}$ & 937 & 67.5 & 67.6 & 5.3 & 57.0 & 77.8 & 823 & 66.1 & 65.9 & 3.4 & 58.8 & 72.2 \\
\hline $\begin{array}{l}\text { Base Load } \\
(\mathrm{kWh} / \text { day) }\end{array}$ & 937 & 28.3 & 29.1 & 10.2 & 11.2 & 50.6 & 823 & 26.0 & 26.5 & 7.4 & 13.4 & 42.4 \\
\hline
\end{tabular}

* Heating slopes tend to create errors in low-load homes and thus lower passing rates.

Table 9 describes the confidence intervals for each parameter across the community. In general, the $95 \%$ confidence interval is small, and although the heating slope and change point show the largest differences, they are to be "taken with a grain of salt" because it is a hot climate. Individual homes with very high values for the interval could have experienced changes in building performance over the course of 3 years, meaning potential changes in occupant behavior or equipment malfunctions.

When the team compared the full dataset to a slice of 1 year, the results shifted, as shown in Table 10. If the data pool is small with limited points from which to sample for modeling, the results can be distorted. A single random sample as displayed in Table 10 varies dramatically from the distribution of results, highlighting the importance of carefully choosing the data to be input into the model. 
Table 9. Confidence Intervals of Inlier Models

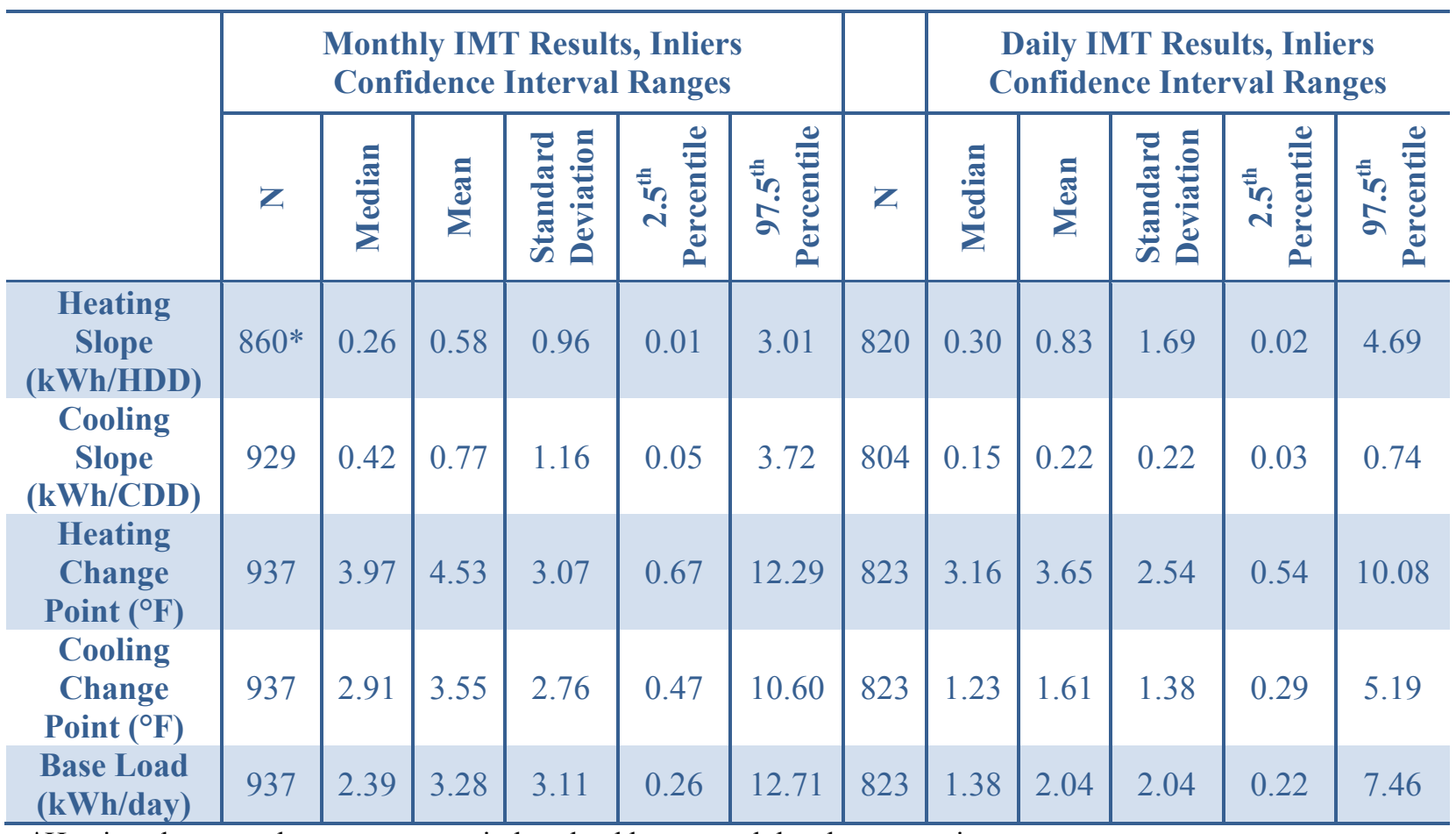

*Heating slopes tend to create errors in low-load homes and thus lower passing rates. 
Table 10. Single-Year Average IMT Results of Inlier Models

\begin{tabular}{|c|c|c|c|c|c|c|c|c|c|c|c|c|}
\hline & \multicolumn{6}{|c|}{$\begin{array}{l}\text { Monthly IMT Results, Inliers } \\
\text { (\% Change from 3-Year Result) }\end{array}$} & \multicolumn{6}{|c|}{$\begin{array}{l}\text { Daily IMT Results, Inliers } \\
\text { (\% Change from 3-Year Result) }\end{array}$} \\
\hline & Z & : & 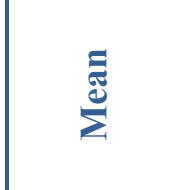 & 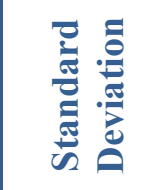 & ت & 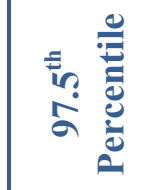 & Z & : & $\sum_{\Sigma}^{\bar{E}}$ & 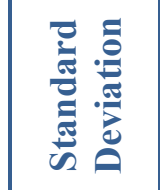 & ت & 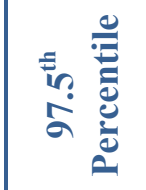 \\
\hline $\begin{array}{l}\text { Heating Slope } \\
\text { (kWh/HDD) }\end{array}$ & 306 & $\begin{array}{c}0.55 \\
(47.6 \%)\end{array}$ & $\begin{array}{c}1.85 \\
(-26.2 \%)\end{array}$ & $\begin{array}{c}3.02 \\
(-44.9 \%)\end{array}$ & $\begin{array}{c}10.36 \\
(-43.3 \%)\end{array}$ & $\begin{array}{c}0.11 \\
(-5.4 \%)\end{array}$ & 306 & $\begin{array}{c}-0.86 \\
(11.5 \%)\end{array}$ & $\begin{array}{c}-1.45 \\
(13.8 \%)\end{array}$ & $\begin{array}{c}1.89 \\
(16.2 \%)\end{array}$ & $\begin{array}{l}-5.46 \\
(34.7 \%)\end{array}$ & $\begin{array}{c}-0.2 \\
(25.7 \%)\end{array}$ \\
\hline $\begin{array}{l}\text { Cooling Slope } \\
\text { (kWh/CDD) }\end{array}$ & 299 & $\begin{array}{c}1.38 \\
(33.6 \%)\end{array}$ & $\begin{array}{c}1.41 \\
(55.8 \%)\end{array}$ & $\begin{array}{c}0.42 \\
(252.2 \%)\end{array}$ & $\begin{array}{c}0.7 \\
(11.9 \%)\end{array}$ & $\begin{array}{c}2.35 \\
(169.9 \%)\end{array}$ & 332 & $\begin{array}{c}1.69 \\
(3.6 \%)\end{array}$ & $\begin{array}{c}1.79 \\
(1.5 \%)\end{array}$ & $\begin{array}{c}0.5 \\
(3.9 \%)\end{array}$ & $\begin{array}{l}1.04 \\
(-4 \%)\end{array}$ & $\begin{array}{c}2.85 \\
(2.3 \%)\end{array}$ \\
\hline $\begin{array}{l}\text { Heating Change } \\
\text { Point }\left({ }^{\circ} \mathbf{F}\right)\end{array}$ & 301 & $\begin{array}{l}55.36 \\
(5.2 \%)\end{array}$ & $\begin{array}{l}55.16 \\
(5.8 \%)\end{array}$ & $\begin{array}{c}6.16 \\
(-2.4 \%)\end{array}$ & $\begin{array}{l}47.34 \\
(-1 \%)\end{array}$ & $\begin{array}{c}65.39 \\
(6.6 \%)\end{array}$ & 333 & $\begin{array}{c}57.59 \\
(-5.7 \%)\end{array}$ & $\begin{array}{c}55.55 \\
(-2.1 \%)\end{array}$ & $\left|\begin{array}{c}7.42 \\
(-20.8 \%)\end{array}\right|$ & $\begin{array}{l}41.7 \\
(4 \%)\end{array}$ & $\begin{array}{c}66.71 \\
(-0.2 \%)\end{array}$ \\
\hline $\begin{array}{l}\text { Cooling Change } \\
\text { Point }\left({ }^{\circ} \mathbf{F}\right)\end{array}$ & 301 & $\begin{array}{l}63.38 \\
(6.4 \%)\end{array}$ & $\begin{array}{l}63.71 \\
(6.1 \%)\end{array}$ & $\begin{array}{c}3.45 \\
(54 \%)\end{array}$ & $\begin{array}{l}52.69 \\
(8.2 \%)\end{array}$ & $\begin{array}{c}70.07 \\
(11 \%)\end{array}$ & 333 & $\begin{array}{c}66.71 \\
(-0.9 \%)\end{array}$ & $\begin{array}{c}65.63 \\
(0.4 \%)\end{array}$ & $\begin{array}{c}3.59 \\
(-5.5 \%)\end{array}$ & $\begin{array}{l}57.59 \\
(2.1 \%)\end{array}$ & $\begin{array}{l}72.19 \\
(0 \%)\end{array}$ \\
\hline $\begin{array}{l}\text { Base Load } \\
\text { (kWh/day) }\end{array}$ & 301 & $\begin{array}{c}33.07 \\
(-14.6 \%)\end{array}$ & $\begin{array}{c}33.6 \\
(-13.4 \%)\end{array}$ & $\begin{array}{c}9.41 \\
(8.3 \%)\end{array}$ & $\begin{array}{c}15.38 \\
(-27 \%)\end{array}$ & $\begin{array}{c}55.22 \\
(-8.4 \%)\end{array}$ & 333 & $\begin{array}{c}27.82 \\
(-6.6 \%)\end{array}$ & $\begin{array}{c}27.99 \\
(-5.4 \%)\end{array}$ & $\begin{array}{l}7.52 \\
(-1 \%)\end{array}$ & $\begin{array}{l}13.23 \\
(1 \%)\end{array}$ & $\begin{array}{c}44 \\
(-3.7 \%)\end{array}$ \\
\hline
\end{tabular}




\subsection{Grouping by Plan Type, Square Footage, Occupancy, and Orientation}

The research team performed further slicing of the set of models into groups by floor plan, occupancy, square footage, and orientation. The results previously reported are the results for the pooled community. In this particular case, the community is fairly homogeneous; however, a subset of homes is newer, with higher performing attributes.

\subsubsection{Plan Types}

Table 11 through Table 13 show the relative differences in results when houses are sorted by either single-story ranch or two-story duplex plan type. The largest variation in the data from monthly to daily at a high level is the difference in heating change points and heating slopes for these two different plan types. The problem with that is heating loads in this climate zone (hothumid) are low and do not use much electricity for heating. The cooling slopes are almost identical, and the base load for the ranch houses is slightly lower than that of the duplexes. Change points are similar to those presented in Table 11 and follow the same pattern.

Table 11. IMT Results on Ranch-Type Houses (Total $n=857$ )

\begin{tabular}{|c|c|c|c|c|c|c|c|c|c|c|}
\hline & \multicolumn{5}{|c|}{$\begin{array}{l}\text { Daily IMT Results, Ranch Inliers } \\
\qquad(\mathrm{n}=363)\end{array}$} & \multicolumn{5}{|c|}{$\begin{array}{l}\text { Monthly IMT Results, Ranch Inliers } \\
\qquad(\mathrm{n}=\mathbf{2 8 7})\end{array}$} \\
\hline & 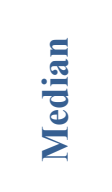 & 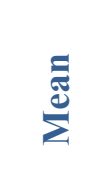 & 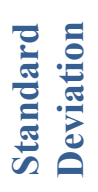 & 望总 & 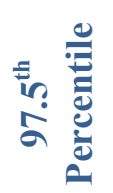 & 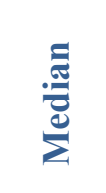 & $\sum_{\bar{E}}^{\Xi}$ & 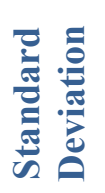 & 望 & in \\
\hline $\begin{array}{l}\text { Heating Slope } \\
\text { (kWh/HDD) }\end{array}$ & 1.85 & 2.07 & 1.26 & 5.18 & 0.39 & 1.45 & 1.84 & 1.20 & 4.41 & 0.57 \\
\hline $\begin{array}{l}\text { Cooling Slope } \\
\text { (kWh/CDD) }\end{array}$ & 1.45 & 1.52 & 0.70 & 0.40 & 3.00 & 1.37 & 1.46 & 0.73 & 0.51 & 3.35 \\
\hline $\begin{array}{c}\text { Heating Change } \\
\text { Point }\left({ }^{\circ} \mathrm{F}\right)\end{array}$ & 55 & 55 & 3.4 & 50.9 & 62 & 59.1 & 60 & 2.7 & 56.3 & 67.1 \\
\hline $\begin{array}{c}\text { Cooling Change } \\
\text { Point }\left({ }^{\circ} \mathrm{F}\right)\end{array}$ & 67.4 & 67 & 5.5 & 55.6 & 75.6 & 64.7 & 65.9 & 5.7 & 59.1 & 75.9 \\
\hline $\begin{array}{l}\text { Base Load } \\
\text { (kWh/day) }\end{array}$ & 30.39 & 31.71 & 8.01 & 14.55 & 48.97 & 31.32 & 30.67 & 8.80 & 11.20 & 47.11 \\
\hline CV-RMSE & $33 \%$ & $34 \%$ & $8 \%$ & $23 \%$ & $52 \%$ & $12 \%$ & $12 \%$ & $5 \%$ & $4 \%$ & $19 \%$ \\
\hline
\end{tabular}

$\mathrm{n}$ is the number of houses. 
Table 12. IMT Results on Duplex-Type Houses (Total $n=857$ )

\begin{tabular}{c|c|c|c|c|c|c|c|c|c|c}
\hline \multirow{2}{*}{} & \multicolumn{7}{|c|}{ Daily IMT Results, Duplex Inliers } & \multicolumn{3}{c}{ Monthly IMT Results, Duplex Inliers } \\
(n=363)
\end{tabular}

$\mathrm{n}$ is the number of houses.

Table 13. Percent Change Between Duplex and Ranch-Type Houses

\begin{tabular}{|c|c|c|c|c|c|c|c|c|c|c|}
\hline & \multicolumn{5}{|c|}{$\begin{array}{c}\text { Percent Change From Duplex to } \\
\text { Ranch, Daily Data }\end{array}$} & \multicolumn{5}{|c|}{$\begin{array}{l}\text { Percent Change From Duplex to } \\
\text { Ranch, Monthly Data }\end{array}$} \\
\hline & 莺 & $\sum_{\Sigma}^{E}$ & 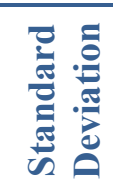 & 望 & 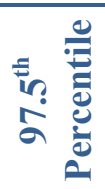 & 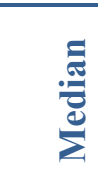 & $\underset{\Sigma}{\mathbb{E}}$ & 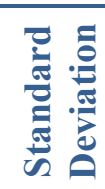 & 望 & 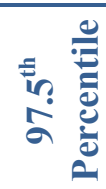 \\
\hline $\begin{array}{l}\text { Heating Slope } \\
\text { (kWh/HDD) }\end{array}$ & $112 \%$ & $119 \%$ & $183 \%$ & $169 \%$ & $42 \%$ & $62 \%$ & $86 \%$ & $123 \%$ & $91 \%$ & $162 \%$ \\
\hline $\begin{array}{l}\text { Cooling Slope } \\
\text { (kWh/CDD) }\end{array}$ & $0 \%$ & $1 \%$ & $21 \%$ & $-31 \%$ & $3 \%$ & $-5 \%$ & $-4 \%$ & $10 \%$ & $4 \%$ & $11 \%$ \\
\hline $\begin{array}{l}\text { Heating Change } \\
\text { Point }\left({ }^{\circ} \mathrm{F}\right)\end{array}$ & $-4 \%$ & $-4 \%$ & $-25 \%$ & $0 \%$ & $-8 \%$ & $-2 \%$ & $-1 \%$ & $-12 \%$ & $0 \%$ & $-3 \%$ \\
\hline $\begin{array}{l}\text { Cooling Change } \\
\text { Point }\left({ }^{\circ} \mathrm{F}\right)\end{array}$ & $0 \%$ & $-1 \%$ & $25 \%$ & $-6 \%$ & $0 \%$ & $-4 \%$ & $-1 \%$ & $32 \%$ & $0 \%$ & $2 \%$ \\
\hline $\begin{array}{l}\text { Base Load } \\
\text { (kWh/day) }\end{array}$ & $8 \%$ & $11 \%$ & $-2 \%$ & $4 \%$ & $7 \%$ & $10 \%$ & $7 \%$ & $-3 \%$ & $-7 \%$ & $-5 \%$ \\
\hline
\end{tabular}

\subsubsection{Square Footage}

Table 14 through Table 18 show that when houses are separated by square footage, the results are similar to those of sorting by plan type. Houses from 1,100 to 1,500 $\mathrm{ft}^{2}$ appear to have similar characteristics to the ranch plan type, and the 1,500- to 1,700- $\mathrm{ft}^{2}$ houses appear to be the duplex houses. Heating results here show a possible significant difference between monthly and daily data, but that should be expected in this climate and ignored. The base loads for each group increase as the houses become larger. 
One might have expected cooling slopes to increase as the square footage increased; however, in this case, they did not. No thorough multiple linear regression was completed to determine the significance of the individual building characteristics, but this will be attempted in the future.

Table 14. IMT Results on Small Square Footage

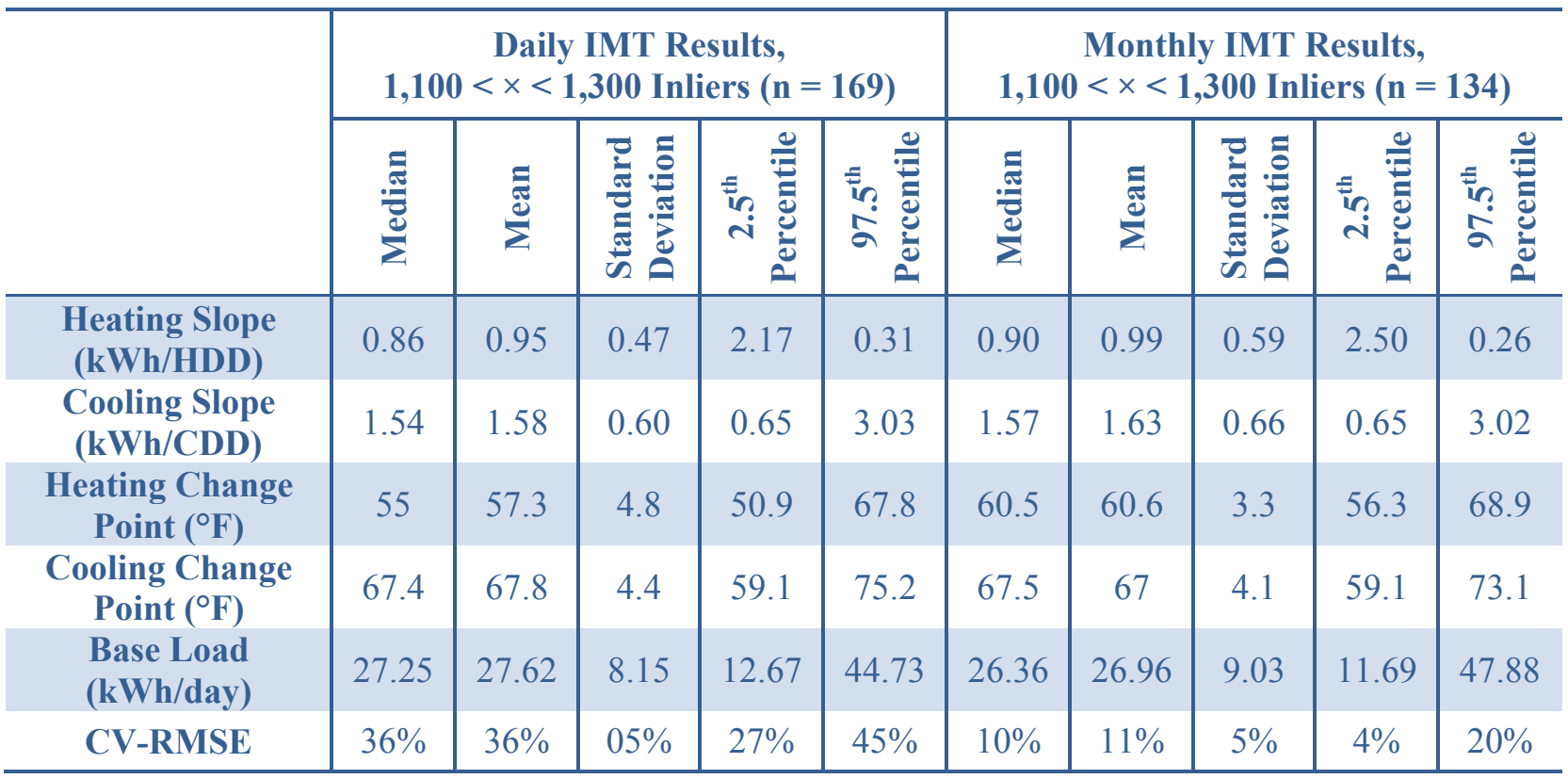

$\mathrm{n}$ is the number of houses.

Table 15. IMT Results on Medium Square Footage

\begin{tabular}{|c|c|c|c|c|c|c|c|c|c|c|}
\hline & \multicolumn{5}{|c|}{$\begin{array}{c}\text { Daily IMT Results, } \\
1,100<\times<1,300 \text { Inliers }(n=194)\end{array}$} & \multicolumn{5}{|c|}{$\begin{array}{c}\text { Monthly IMT Results, } \\
1,100<x<1,300 \text { Inliers }(n=134)\end{array}$} \\
\hline & 苞 & $\stackrel{\Xi}{\stackrel{\Xi}{E}}$ & 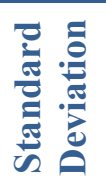 & 点 & 总 & 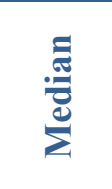 & 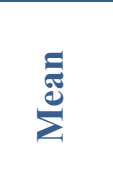 & 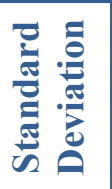 & 党 & 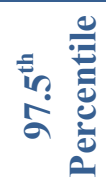 \\
\hline $\begin{array}{l}\text { Heating Slope } \\
\text { (kWh/HDD) }\end{array}$ & 0.87 & 0.94 & 0.42 & 1.85 & 0.18 & 0.89 & 0.98 & 0.49 & 2.28 & 0.14 \\
\hline $\begin{array}{l}\text { Cooling Slope } \\
\text { (kWh/CDD) }\end{array}$ & 1.42 & 1.45 & 0.55 & 0.47 & 2.67 & 1.33 & 1.42 & 0.66 & 0.43 & 2.90 \\
\hline $\begin{array}{l}\text { Heating Change } \\
\text { Point }\left({ }^{\circ} \mathrm{F}\right)\end{array}$ & 57.1 & 57.2 & 4.2 & 50.9 & 65.3 & 60.5 & 60.6 & 3 & 56.3 & 68.9 \\
\hline $\begin{array}{l}\text { Cooling Change } \\
\text { Point }\left({ }^{\circ} \mathbf{F}\right)\end{array}$ & 67.4 & 67.1 & 4.4 & 57.1 & 75.6 & 67.5 & 66.5 & 4.4 & 59.1 & 74.5 \\
\hline $\begin{array}{l}\text { Base Load } \\
(\mathrm{kWh} / \text { day })\end{array}$ & 29.65 & 29.55 & 8.15 & 15.86 & 46.00 & 29.66 & 29.97 & 8.90 & 14.19 & 49.71 \\
\hline CV-RMSE & $35 \%$ & $35 \%$ & $5 \%$ & $28 \%$ & $47 \%$ & $9 \%$ & $10 \%$ & $4 \%$ & $4 \%$ & $19 \%$ \\
\hline
\end{tabular}

$\mathrm{n}$ is the number of houses. 
Table 16. IMT Results on Large Square Footage

\begin{tabular}{|c|c|c|c|c|c|c|c|c|c|c|}
\hline & \multicolumn{5}{|c|}{$\begin{array}{c}\text { Daily IMT Results, } \\
1,500<x<1,700 \text { Inliers }(n=65)\end{array}$} & \multicolumn{5}{|c|}{$\begin{array}{c}\text { Monthly IMT Results, } \\
1,500<x<1,700 \text { Inliers }(n=51)\end{array}$} \\
\hline & 胥 & $\sum_{\Sigma}^{\tilde{E}}$ & 气̃ & 总 & 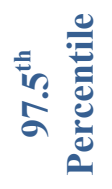 & 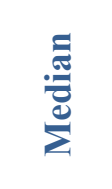 & 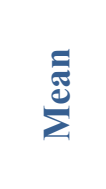 & 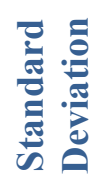 & 总 & 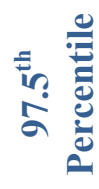 \\
\hline $\begin{array}{l}\text { Heating Slope } \\
\text { (kWh/HDD) }\end{array}$ & 1.85 & 2.07 & 1.26 & 5.18 & 0.39 & 1.45 & 1.84 & 1.20 & 4.41 & 0.57 \\
\hline $\begin{array}{l}\text { Cooling Slope } \\
\text { (kWh/CDD) }\end{array}$ & 1.45 & 1.52 & 0.70 & 0.40 & 3.00 & 1.37 & 0.82 & 0.14 & 0.47 & 0.97 \\
\hline $\begin{array}{l}\text { Heating Change } \\
\text { Point }\left({ }^{\circ} \mathbf{F}\right)\end{array}$ & 55 & 55 & 3.4 & 50.9 & 62 & 59.1 & -1.8 & 1.2 & -4.4 & -0.6 \\
\hline $\begin{array}{l}\text { Cooling Change } \\
\text { Point }\left({ }^{\circ} \mathbf{F}\right)\end{array}$ & 67.4 & 67 & 5.5 & 55.6 & 75.6 & 64.7 & 65.9 & 5.7 & 59.1 & 75.9 \\
\hline $\begin{array}{l}\text { Base Load } \\
\text { (kWh/day) }\end{array}$ & 30.39 & 31.71 & 8.01 & 14.55 & 48.97 & 31.32 & 30.67 & 8.80 & 11.20 & 47.11 \\
\hline CV-RMSE & $33 \%$ & $34 \%$ & $8 \%$ & $23 \%$ & $52 \%$ & $12 \%$ & $12 \%$ & $5 \%$ & $4 \%$ & $19 \%$ \\
\hline
\end{tabular}

$\mathrm{n}$ is the number of houses.

Table 17. Percent Change From Small to Medium Square Footage

\begin{tabular}{|c|c|c|c|c|c|c|c|c|c|c|}
\hline & \multicolumn{5}{|c|}{$\begin{array}{l}\text { Daily Percent Change From Small } \\
\text { to Medium Square Footage }\end{array}$} & \multicolumn{5}{|c|}{$\begin{array}{c}\text { Monthly Percent Change From Small to } \\
\text { Medium Square Footage }\end{array}$} \\
\hline & 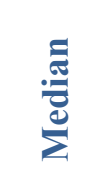 & $\stackrel{\Xi}{\sum_{\Sigma}^{E}}$ & 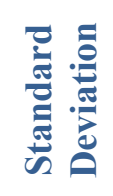 & 望 & 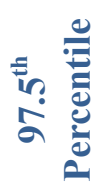 & 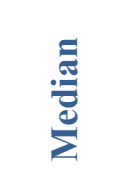 & $\sum_{\Sigma}^{\Xi}$ & 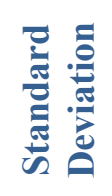 & 望 & 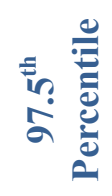 \\
\hline $\begin{array}{l}\text { Heating Slope } \\
\text { (kWh/HDD) }\end{array}$ & $1 \%$ & $-1 \%$ & $-11 \%$ & $-15 \%$ & $-42 \%$ & $-1 \%$ & $-2 \%$ & $-16 \%$ & $-9 \%$ & $-46 \%$ \\
\hline $\begin{array}{c}\text { Cooling Slope } \\
\text { (kWh/CDD) }\end{array}$ & $-8 \%$ & $-8 \%$ & $-8 \%$ & $-28 \%$ & $-12 \%$ & $-15 \%$ & $-13 \%$ & $0 \%$ & $-33 \%$ & $-4 \%$ \\
\hline $\begin{array}{c}\text { Heating Change } \\
\text { Point }\left({ }^{\circ} \mathbf{F}\right)\end{array}$ & $4 \%$ & $0 \%$ & $-13 \%$ & $0 \%$ & $-4 \%$ & $0 \%$ & $0 \%$ & $-10 \%$ & $0 \%$ & $0 \%$ \\
\hline $\begin{array}{l}\text { Cooling Change } \\
\text { Point }\left({ }^{\circ} \mathrm{F}\right)\end{array}$ & $0 \%$ & $-1 \%$ & $1 \%$ & $-3 \%$ & $1 \%$ & $0 \%$ & $-1 \%$ & $7 \%$ & $0 \%$ & $2 \%$ \\
\hline $\begin{array}{l}\text { Base Load } \\
(\mathrm{kWh} / \text { day })\end{array}$ & $9 \%$ & $7 \%$ & $0 \%$ & $25 \%$ & $3 \%$ & $13 \%$ & $11 \%$ & $-1 \%$ & $21 \%$ & $4 \%$ \\
\hline
\end{tabular}


Table 18. Percent Change From Medium to Large Square Footage

\begin{tabular}{|c|c|c|c|c|c|c|c|c|c|c|}
\hline & \multicolumn{5}{|c|}{$\begin{array}{l}\text { Daily Percent Change From } \\
\text { Medium to Large Square Footage }\end{array}$} & \multicolumn{5}{|c|}{$\begin{array}{l}\text { Monthly Percent Change From } \\
\text { Medium to Large Square Footage }\end{array}$} \\
\hline & 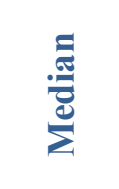 & 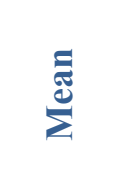 & 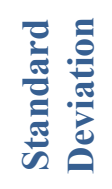 & 苋 & 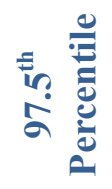 & 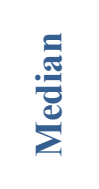 & $\sum^{\mathbb{E}}$ & 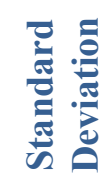 & 芯 & 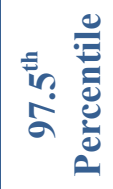 \\
\hline $\begin{array}{l}\text { Heating Slope } \\
\text { (kWh/HDD) }\end{array}$ & $111 \%$ & $120 \%$ & $199 \%$ & $181 \%$ & $115 \%$ & $63 \%$ & $88 \%$ & $143 \%$ & $93 \%$ & $300 \%$ \\
\hline $\begin{array}{l}\text { Cooling Slope } \\
\text { (kWh/CDD) }\end{array}$ & $2 \%$ & $5 \%$ & $26 \%$ & $-16 \%$ & $12 \%$ & $3 \%$ & $-42 \%$ & $-79 \%$ & $9 \%$ & $-66 \%$ \\
\hline $\begin{array}{l}\text { Heating Change } \\
\text { Point }\left({ }^{\circ} \mathbf{F}\right)\end{array}$ & $-4 \%$ & $-4 \%$ & $-20 \%$ & $0 \%$ & $-5 \%$ & $-2 \%$ & $-1 \%$ & $-7 \%$ & $0 \%$ & $-3 \%$ \\
\hline $\begin{array}{l}\text { Cooling Change } \\
\text { Point }\left({ }^{\circ} \mathbf{F}\right)\end{array}$ & $0 \%$ & $0 \%$ & $25 \%$ & $-3 \%$ & $0 \%$ & $-4 \%$ & $-1 \%$ & $28 \%$ & $0 \%$ & $2 \%$ \\
\hline $\begin{array}{l}\text { Base Load } \\
(\mathrm{kWh} / \text { day })\end{array}$ & $2 \%$ & $7 \%$ & $-2 \%$ & $-8 \%$ & $6 \%$ & $6 \%$ & $2 \%$ & $-1 \%$ & $-21 \%$ & $-5 \%$ \\
\hline
\end{tabular}

\subsubsection{Occupancy}

Table 19 through Table 22 show the difference in results when houses are sorted by number of occupants. Occupancy also might correlate with square footage, hence biasing this analysis. In other words, the observed difference between two and three occupants might actually be square footage. A multiple linear regression would help to determine whether the number of occupants is a significant factor, but this was not completed for this report. 
Table 19. IMT Results on Two Occupants

\begin{tabular}{|c|c|c|c|c|c|c|c|c|c|c|}
\hline & \multicolumn{5}{|c|}{$\begin{array}{c}\text { Daily IMT Results, Two } \\
\text { Occupants, Inliers }(\mathrm{n}=156)\end{array}$} & \multicolumn{5}{|c|}{$\begin{array}{l}\text { Monthly IMT Results, Two } \\
\text { Occupants, Inliers }(\mathrm{n}=111)\end{array}$} \\
\hline & 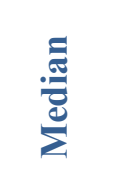 & 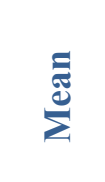 & 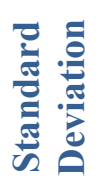 & 雚 & 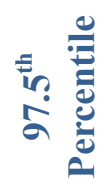 & 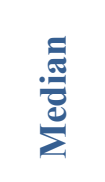 & $\sum_{\Sigma}^{\tilde{E}}$ & 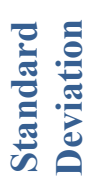 & 点 & 苋 \\
\hline $\begin{array}{l}\text { Heating Slope } \\
\text { (kWh/HDD) }\end{array}$ & 0.85 & 0.92 & 0.48 & 2.27 & 0.23 & 0.89 & 1.00 & 0.58 & 2.27 & 0.25 \\
\hline $\begin{array}{l}\text { Cooling Slope } \\
\text { (kWh/CDD) }\end{array}$ & 1.50 & 1.52 & 0.57 & 0.57 & 2.81 & 1.48 & 1.56 & 0.62 & 0.62 & 3.01 \\
\hline $\begin{array}{l}\text { Heating Change } \\
\text { Point }\left({ }^{\circ} \mathrm{F}\right)\end{array}$ & 57.1 & 57.2 & 4.4 & 50.9 & 67.4 & 60.5 & 60.8 & 3.3 & 56.3 & 68.9 \\
\hline $\begin{array}{l}\text { Cooling Change } \\
\text { Point }\left({ }^{\circ} \mathbf{F}\right)\end{array}$ & 67.4 & 67.5 & 4.4 & 58.9 & 75.6 & 67.5 & 66.9 & 4.3 & 59.1 & 74.5 \\
\hline $\begin{array}{l}\text { Base Load } \\
\text { (kWh/day) }\end{array}$ & 25.95 & 26.66 & 7.47 & 14.30 & 44.63 & 25.33 & 25.68 & 8.01 & 13.48 & 47.68 \\
\hline CV-RMSE & $35 \%$ & $36 \%$ & $6 \%$ & $27 \%$ & $45 \%$ & $10 \%$ & $11 \%$ & $4 \%$ & $4 \%$ & $19 \%$ \\
\hline
\end{tabular}

$\mathrm{n}$ is the number of houses.

Table 20. IMT Results on Three Occupants

\begin{tabular}{|c|c|c|c|c|c|c|c|c|c|c|}
\hline & \multicolumn{5}{|c|}{$\begin{array}{l}\text { Daily IMT Results, Three } \\
\text { Occupants, Inliers }(\mathrm{n}=\mathbf{2 7 2})\end{array}$} & \multicolumn{5}{|c|}{$\begin{array}{l}\text { Monthly IMT Results, Three } \\
\text { Occupants, Inliers }(n=227)\end{array}$} \\
\hline & 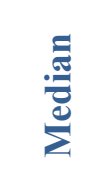 & 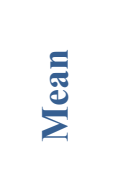 & 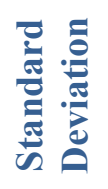 & 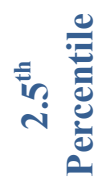 & 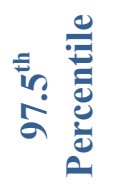 & 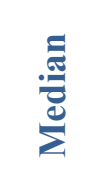 & 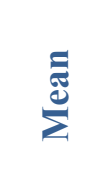 & 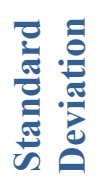 & 苋 & 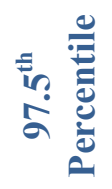 \\
\hline $\begin{array}{l}\text { Heating Slope } \\
\text { (kWh/HDD) }\end{array}$ & 1.00 & 1.23 & 0.85 & 3.74 & 0.30 & 1.01 & 1.17 & 0.81 & 3.76 & 0.19 \\
\hline $\begin{array}{l}\text { Cooling Slope } \\
\text { (kWh/CDD) }\end{array}$ & 1.44 & 1.50 & 0.61 & 0.51 & 2.96 & 1.39 & 1.48 & 0.70 & 0.49 & 3.10 \\
\hline $\begin{array}{c}\text { Heating Change } \\
\text { Point }\left({ }^{\circ} \mathbf{F}\right)\end{array}$ & 55 & 56.7 & 4.4 & 50.9 & 67.4 & 60.5 & 60.4 & 2.9 & 56.3 & 68.9 \\
\hline $\begin{array}{l}\text { Cooling Change } \\
\text { Point }\left({ }^{\circ} \mathrm{F}\right)\end{array}$ & 67.4 & 67.3 & 4.7 & 57.1 & 75.6 & 67.5 & 66.5 & 4.6 & 59.1 & 74.5 \\
\hline $\begin{array}{l}\text { Base Load } \\
\text { (kWh/day) }\end{array}$ & 30.20 & 30.52 & 8.33 & 14.17 & 47.59 & 30.64 & 30.45 & 9.13 & 11.17 & 49.67 \\
\hline CV-RMSE & $35 \%$ & $35 \%$ & $5 \%$ & $26 \%$ & $47 \%$ & $10 \%$ & $11 \%$ & $4 \%$ & $4 \%$ & $19 \%$ \\
\hline
\end{tabular}

$\mathrm{n}$ is the number of houses. 
Table 21. Percent Change From Three to Two Occupants

\begin{tabular}{|c|c|c|c|c|c|c|c|c|c|c|}
\hline & \multicolumn{5}{|c|}{$\begin{array}{l}\text { Daily Percent Change From } \\
\text { Three to Two Occupants }\end{array}$} & \multicolumn{5}{|c|}{$\begin{array}{l}\text { Monthly Percent Change From } \\
\text { Three to Two Occupants }\end{array}$} \\
\hline & 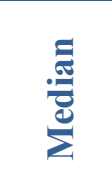 & 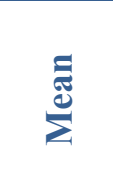 & 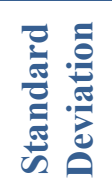 & 望 & مَ & 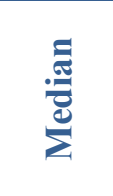 & $\sum_{\Sigma}^{\Xi}$ & 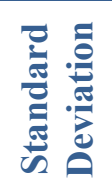 & 点 & 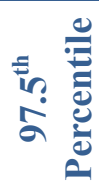 \\
\hline $\begin{array}{l}\text { Heating Slope } \\
\text { (kWh/HDD) }\end{array}$ & $-16 \%$ & $-25 \%$ & $-43 \%$ & $-39 \%$ & $-24 \%$ & $-11 \%$ & $-14 \%$ & $-28 \%$ & $-40 \%$ & $29 \%$ \\
\hline $\begin{array}{l}\text { Cooling Slope } \\
\text { (kWh/CDD) }\end{array}$ & $4 \%$ & $1 \%$ & $-7 \%$ & $11 \%$ & $-5 \%$ & $7 \%$ & $5 \%$ & $-10 \%$ & $28 \%$ & $-3 \%$ \\
\hline $\begin{array}{l}\text { Heating Change } \\
\text { Point }\left({ }^{\circ} \mathbf{F}\right)\end{array}$ & $4 \%$ & $1 \%$ & $0 \%$ & $0 \%$ & $0 \%$ & $0 \%$ & $1 \%$ & $14 \%$ & $0 \%$ & $0 \%$ \\
\hline $\begin{array}{l}\text { Cooling Change } \\
\text { Point }\left({ }^{\circ} \mathbf{F}\right)\end{array}$ & $0 \%$ & $0 \%$ & $-7 \%$ & $3 \%$ & $0 \%$ & $0 \%$ & $1 \%$ & $-6 \%$ & $0 \%$ & $0 \%$ \\
\hline $\begin{array}{l}\text { Base Load } \\
\text { (kWh/day) }\end{array}$ & $-14 \%$ & $-13 \%$ & $-10 \%$ & $1 \%$ & $-6 \%$ & $17 \%$ & $-16 \%$ & $-12 \%$ & $21 \%$ & $-4 \%$ \\
\hline
\end{tabular}

Table 22. Percent Change From Monthly to Daily, Two and Three Occupants

\begin{tabular}{|c|c|c|c|c|c|c|c|c|c|c|}
\hline & \multicolumn{5}{|c|}{ Two Occupants } & \multicolumn{5}{|c|}{ Three Occupants } \\
\hline & 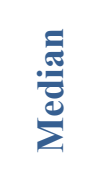 & 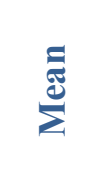 & 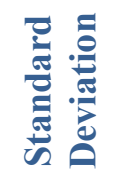 & 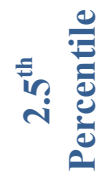 & in & 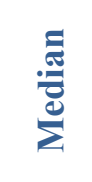 & 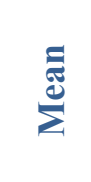 & 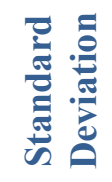 & 的总 & 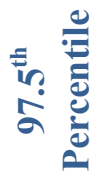 \\
\hline $\begin{array}{l}\text { Heating Slope } \\
\text { (kWh/HDD) }\end{array}$ & $-5 \%$ & $-8 \%$ & $-17 \%$ & $0 \%$ & $-8 \%$ & $-1 \%$ & $5 \%$ & $6 \%$ & $-1 \%$ & $57 \%$ \\
\hline $\begin{array}{l}\text { Cooling Slope } \\
\text { (kWh/CDD) }\end{array}$ & $1 \%$ & $-2 \%$ & $-9 \%$ & $-9 \%$ & $-7 \%$ & $4 \%$ & $1 \%$ & $-12 \%$ & $6 \%$ & $-4 \%$ \\
\hline $\begin{array}{c}\text { Heating } \\
\text { Change Point } \\
\left({ }^{\circ} \mathbf{F}\right)\end{array}$ & $-6 \%$ & $-6 \%$ & $32 \%$ & $-10 \%$ & $-2 \%$ & $-9 \%$ & $-6 \%$ & $51 \%$ & $-10 \%$ & $-2 \%$ \\
\hline $\begin{array}{c}\text { Cooling Change } \\
\text { Point }\left({ }^{\circ} \mathrm{F}\right)\end{array}$ & $0 \%$ & $1 \%$ & $2 \%$ & $0 \%$ & $2 \%$ & $0 \%$ & $1 \%$ & $2 \%$ & $-3 \%$ & $2 \%$ \\
\hline $\begin{array}{l}\text { Base Load } \\
\text { (kWh/day) }\end{array}$ & $2 \%$ & $4 \%$ & $-7 \%$ & $6 \%$ & $-6 \%$ & $-1 \%$ & $0 \%$ & $-9 \%$ & $27 \%$ & $-4 \%$ \\
\hline
\end{tabular}

\subsubsection{Orientation}

Table 23 through Table 26 present the differences and percent differences between each subset of homes of a particular orientation and the average of all homes. The data clearly register an increase in cooling slope for the south-facing houses. The south orientation experienced a $12 \%$ increase over the others, as shown in Table 23. 
Table 23. Difference Between Orientations and the Mean $(n=428)$

\begin{tabular}{|c|c|c|c|c|c|c|c|c|c|}
\hline & \multicolumn{9}{|c|}{ Daily IMT Results, Orientation, Inliers $(n=428)$} \\
\hline & \multirow{2}{*}{ Mean } & \multicolumn{8}{|c|}{ Deviation From Mean } \\
\hline & & $\mathbf{S}$ & SW & $\mathbf{W}$ & NW & $\mathbf{N}$ & NE & $\mathbf{E}$ & SE \\
\hline $\begin{array}{c}\text { Number of } \\
\text { Houses }\end{array}$ & & 31 & 86 & 38 & 61 & 19 & 81 & 46 & 66 \\
\hline $\begin{array}{l}\text { Heating Slope } \\
\text { (kWh/HDD) }\end{array}$ & 1.1 & -0.19 & 0.025 & -0.033 & 0.038 & 0.001 & 0.028 & -0.018 & 0.151 \\
\hline $\begin{array}{l}\text { Cooling Slope } \\
\text { (kWh/CDD) }\end{array}$ & 1.5 & 0.202 & -0.193 & -0.059 & -0.129 & 0.023 & -0.055 & 0.186 & 0.025 \\
\hline $\begin{array}{l}\text { Heating Change } \\
\text { Point }\left({ }^{\circ} \mathbf{F}\right)\end{array}$ & 60.64 & 1.23 & -0.44 & 0.94 & -0.58 & -0.53 & 0.08 & -0.36 & -0.34 \\
\hline $\begin{array}{l}\text { Cooling Change } \\
\text { Point }\left({ }^{\circ} \mathrm{F}\right)\end{array}$ & 66.8 & 0.99 & -0.16 & 0.69 & 0.14 & 0.03 & -0.20 & -0.01 & -1.48 \\
\hline $\begin{array}{l}\text { Base Load } \\
\text { (kWh/day) }\end{array}$ & 28.7 & -3.40 & 0.69 & -5.32 & 4.73 & 5.30 & -1.78 & -1.31 & 1.08 \\
\hline CV-RMSE & $10.7 \%$ & $-0.3 \%$ & $0.3 \%$ & $1.7 \%$ & $-1.8 \%$ & $0.3 \%$ & $1.5 \%$ & $-0.3 \%$ & $-1.4 \%$ \\
\hline
\end{tabular}

$\mathrm{n}$ is the number of houses.

Table 24. Percent Difference Between Orientations and the Mean $(n=428)$

\begin{tabular}{|c|c|c|c|c|c|c|c|c|c|}
\hline & \multicolumn{9}{|c|}{ Daily IMT Results, Orientation, Inliers $(n=428)$} \\
\hline & \multirow{2}{*}{ Mean } & \multicolumn{8}{|c|}{ Percent Deviation From Mean } \\
\hline & & $\mathbf{S}$ & SW & $\mathbf{W}$ & NW & $\mathbf{N}$ & $\mathbf{N E}$ & $\mathbf{E}$ & SE \\
\hline $\begin{array}{c}\text { Number of } \\
\text { Houses }\end{array}$ & & 31 & 86 & 38 & 61 & 19 & 81 & 46 & 66 \\
\hline $\begin{array}{l}\text { Heating Slope } \\
\text { (kWh/HDD) }\end{array}$ & 1.1 & $-20 \%$ & $2 \%$ & $-5 \%$ & $25 \%$ & $8 \%$ & $2 \%$ & $-19 \%$ & $7 \%$ \\
\hline $\begin{array}{l}\text { Cooling Slope } \\
\text { (kWh/CDD) }\end{array}$ & 1.5 & $12 \%$ & $-4 \%$ & $-3 \%$ & $1 \%$ & $1 \%$ & $-1 \%$ & $-1 \%$ & $-5 \%$ \\
\hline $\begin{array}{l}\text { Heating Change } \\
\text { Point }\left({ }^{\circ} \mathrm{F}\right)\end{array}$ & 60.64 & $2 \%$ & $1 \%$ & $1 \%$ & $-1 \%$ & $-1 \%$ & $-1 \%$ & $0 \%$ & $-1 \%$ \\
\hline $\begin{array}{l}\text { Cooling Change } \\
\text { Point }\left({ }^{\circ} \mathbf{F}\right)\end{array}$ & 66.8 & $0 \%$ & $0 \%$ & $1 \%$ & $0 \%$ & $1 \%$ & $0 \%$ & $-1 \%$ & $-1 \%$ \\
\hline $\begin{array}{l}\text { Base Load } \\
\text { (kWh/day) }\end{array}$ & 28.7 & $-9 \%$ & $0 \%$ & $-11 \%$ & $13 \%$ & $7 \%$ & $-2 \%$ & $-3 \%$ & $5 \%$ \\
\hline
\end{tabular}

$\mathrm{n}$ is the number of houses. 
Table 25. Difference Between Orientations and the Mean $(n=338)$

\begin{tabular}{|c|c|c|c|c|c|c|c|c|c|}
\hline & \multicolumn{9}{|c|}{ Monthly IMT Results, Orientation, Inliers $(n=338)$} \\
\hline & \multirow{2}{*}{ Mean } & \multicolumn{8}{|c|}{ Deviations From Mean } \\
\hline & & $\mathbf{S}$ & SW & $\mathbf{W}$ & NW & $\mathbf{N}$ & NE & $\mathbf{E}$ & SE \\
\hline $\begin{array}{c}\text { Number of } \\
\text { Houses }\end{array}$ & & 23 & 61 & 29 & 54 & 19 & 58 & 36 & 58 \\
\hline $\begin{array}{l}\text { Heating Slope } \\
\text { (kWh/HDD) }\end{array}$ & 1.082 & -0.192 & 0.025 & -0.033 & 0.038 & 0.001 & 0.028 & -0.018 & 0.151 \\
\hline $\begin{array}{l}\text { Cooling Slope } \\
\text { (kWh/CDD) }\end{array}$ & 1.532 & 0.202 & -0.193 & -0.059 & -0.129 & 0.023 & -0.055 & 0.186 & 0.025 \\
\hline $\begin{array}{l}\text { Heating Change } \\
\text { Point }\left({ }^{\circ} \mathrm{F}\right)\end{array}$ & 60.64 & 1.23 & -0.44 & 0.94 & -0.58 & -0.53 & 0.08 & -0.36 & -0.34 \\
\hline $\begin{array}{l}\text { Cooling Change } \\
\text { Point }\left({ }^{\circ} \mathrm{F}\right)\end{array}$ & 66.78 & 0.99 & -0.16 & 0.69 & 0.14 & 0.03 & -0.20 & -0.01 & -1.48 \\
\hline $\begin{array}{l}\text { Base Load } \\
\text { (kWh/day) }\end{array}$ & 28.65 & -3.40 & 0.69 & -5.32 & 4.73 & 5.30 & -1.78 & -1.31 & 1.08 \\
\hline CV-RMSE & $10.7 \%$ & $-0.3 \%$ & $0.3 \%$ & $1.7 \%$ & $-1.8 \%$ & $-0.3 \%$ & $1.5 \%$ & $-0.3 \%$ & $-1.4 \%$ \\
\hline
\end{tabular}

$\mathrm{n}$ is the number of houses.

Table 26. Percent Difference Between Orientations and the Mean $(n=338)$

\begin{tabular}{|c|c|c|c|c|c|c|c|c|c|}
\hline & \multicolumn{9}{|c|}{ Monthly IMT Results, Orientation, Inliers $(\mathrm{n}=\mathbf{3 3 8})$} \\
\hline & \multirow{2}{*}{ Mean } & \multicolumn{8}{|c|}{ Percent Deviation From Mean } \\
\hline & & $\mathbf{S}$ & SW & W & NW & $\mathbf{N}$ & NE & $\mathbf{E}$ & SE \\
\hline $\begin{array}{c}\text { Number of } \\
\text { Houses }\end{array}$ & & 23 & 61 & 29 & 54 & 19 & 58 & 36 & 58 \\
\hline $\begin{array}{l}\text { Heating Slope } \\
\text { (kWh/HDD) }\end{array}$ & 1.082 & $-19 \%$ & $18 \%$ & $5 \%$ & $12 \%$ & $-2 \%$ & $5 \%$ & $-17 \%$ & $-2 \%$ \\
\hline $\begin{array}{l}\text { Cooling Slope } \\
\text { (kWh/CDD) }\end{array}$ & 1.532 & $13 \%$ & $-2 \%$ & $2 \%$ & $-2 \%$ & $0 \%$ & $-2 \%$ & $1 \%$ & $-10 \%$ \\
\hline $\begin{array}{l}\text { Heating Change } \\
\text { Point }\left({ }^{\circ} \mathbf{F}\right)\end{array}$ & 60.64 & $2 \%$ & $-1 \%$ & $2 \%$ & $-1 \%$ & $-1 \%$ & $0 \%$ & $-1 \%$ & $-1 \%$ \\
\hline $\begin{array}{c}\text { Cooling Change } \\
\text { Point }\left({ }^{\circ} \mathrm{F}\right)\end{array}$ & 66.78 & $1 \%$ & $0 \%$ & $1 \%$ & $0 \%$ & $0 \%$ & $0 \%$ & $0 \%$ & $-2 \%$ \\
\hline $\begin{array}{l}\text { Base Load } \\
(\mathrm{kWh} / \text { day })\end{array}$ & 28.65 & $-12 \%$ & $2 \%$ & $-19 \%$ & $17 \%$ & $19 \%$ & $-6 \%$ & $-5 \%$ & $4 \%$ \\
\hline
\end{tabular}

$\mathrm{n}$ is the number of houses.

\subsection{Sorting by Energy Consumption}

Figure 11 is a histogram showing the percentage of homes, by end use, in 1,000-kWh bins. The $\mathrm{x}$-axis labels are the maximum of each percentage. More than $85 \%$ of the homes are within one bin in their estimated heating use. Cooling use is more widely distributed; all homes are within a $10,000-\mathrm{kWh}$ range. Base-load use is the widest, with more than $18,000-\mathrm{kWh}$ difference between the highest and lowest users. 


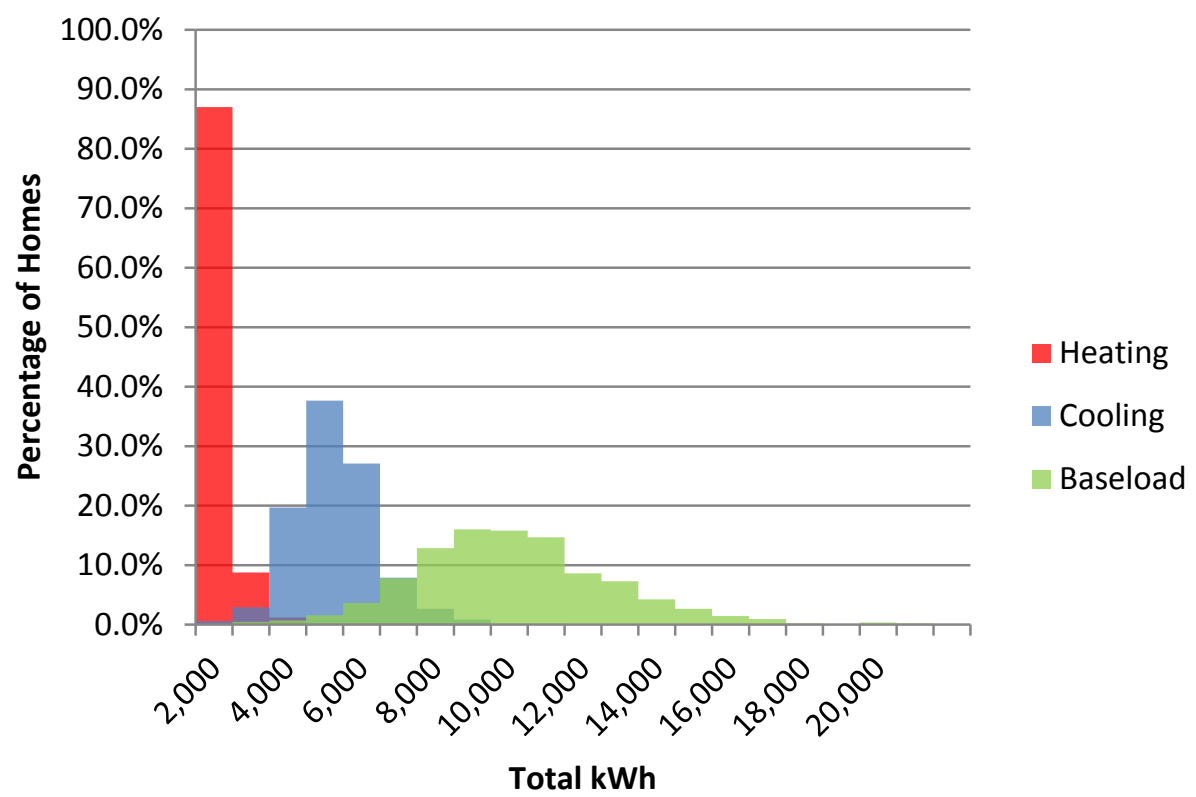

Figure 11. Estimated normalized annual energy consumption per end use, with 2011 temperatures

Of interest and a focus of this research is to isolate the high users - those who, relative to the community, consume the most energy. The inverse models point to the causes of why one user is higher than another. In the case of this community, heating use is a small part of the total energy consumption, and the distribution shows all users are within a small enough range to be arguably insignificant relative to cooling and base-load use.

Table 27 illustrates the breakdown of homes with combinations of cooling and base-load bins. The upper bound of each bin range is included in the range; the lower bound is not included in each range. Base load increases tend to correspond with cooling slope increases, possibly because of the increased cooling load introduced by increased miscellaneous electric consumption. This binned matrix can influence the selection of homes for audits. Homes within a single bin represent narrow bands of performance, and they are expected to have very similar characteristics from an occupant standpoint and with respect to the building enclosure and equipment. 
Table 27. Counts and Percentages of Inlier Homes Within Base Load and Cooling Slope Bins

\begin{tabular}{|c|c|c|c|c|c|c|c|c|}
\hline & & \multicolumn{7}{|c|}{ Cooling Slope Bin (kWh/CDD) } \\
\hline & & $0.0-0.5$ & $0.5-1.0$ & $1.0-1.5$ & $1.5-2.0$ & $2.0-2.5$ & $2.5-3.0$ & 3.0+ \\
\hline \multirow{7}{*}{ 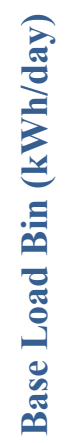 } & $0-10$ & $0.1 \%$ & $0.4 \%$ & $0.2 \%$ & - & - & - & - \\
\hline & $10-20$ & - & $1.5 \%$ & $5.7 \%$ & $6 \%$ & $2.3 \%$ & $0.6 \%$ & - \\
\hline & $20-30$ & - & $0.5 \%$ & $13.7 \%$ & $26 \%$ & $12.6 \%$ & $2.9 \%$ & $0.9 \%$ \\
\hline & $30-40$ & - & $0.1 \%$ & $2.9 \%$ & $11.3 \%$ & $4.6 \%$ & $2.6 \%$ & $0.7 \%$ \\
\hline & $40-50$ & - & - & $0.5 \%$ & $1.1 \%$ & $1.3 \%$ & $0.4 \%$ & $0.2 \%$ \\
\hline & $50-60$ & - & - & - & $20.2 \%$ & $0.1 \%$ & $0.2 \%$ & $0.1 \%$ \\
\hline & $60+$ & - & - & - & - & $10.1 \%$ & - & - \\
\hline
\end{tabular}

\subsection{BEopt Modeling Compared to Utility Data}

The primary differences between simple BEopt models with minimal calibration and the data are in the heating and cooling slopes; BEopt predictions yield lower slopes than those from the utility bill analysis. As in other areas of this analysis, heating coefficients are "taken with a grain of salt" because of their high uncertainty.

Table 28 compares the utility bill data and BEopt simulation IMT results. The primary differences in the results are in the heating and cooling slopes; BEopt predictions yield lower slopes than those from the utility bill analysis. All BEopt runs were inliers; therefore, the sample size is higher. It would be reasonable to replace homes having very noisy data with calibrated BEopt models.

Cooling slopes between the inverse models and the BEopt models are very different. The inverse models suggest much less efficient equipment than is assumed in the BEopt model, which took as input the nameplate efficiencies of the equipment. Change points and base-load values align more closely, but the distributions seen in the utility data appear wider. 
Table 28. Comparison of Utility Bill Data and BEopt Simulation IMT Results

\begin{tabular}{|c|c|c|c|c|c|c|c|c|c|c|}
\hline & \multicolumn{5}{|c|}{$\begin{array}{l}\text { Daily IMT Results, Inliers } \\
(\mathrm{n}=937), \text { Actual Utility Bills }\end{array}$} & \multicolumn{5}{|c|}{$\begin{array}{l}\text { Daily IMT Results, Inliers } \\
(\mathrm{n}=1009) \text {, BEopt Models }\end{array}$} \\
\hline & 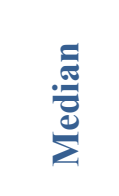 & $\sum^{\tilde{E}}$ & 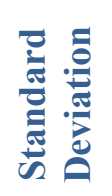 & 蒫 & 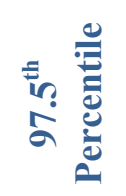 & 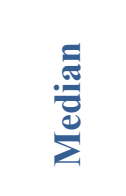 & $\sum_{\bar{E}}^{\bar{E}}$ & 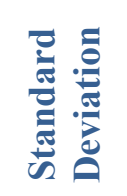 & 䒕 & 吾 \\
\hline $\begin{array}{l}\text { Heating Slope } \\
\text { (kWh/HDD) }\end{array}$ & 0.8 & 1.4 & 1.7 & 0.1 & 5.9 & 1.1 & 1.1 & 0.2 & 0.8 & 1.5 \\
\hline $\begin{array}{l}\text { Cooling Slope } \\
\text { (kWh/CDD) }\end{array}$ & 1.8 & 2.2 & 1.5 & 0.8 & 6.4 & 1.3 & 1.3 & 0.2 & 1.0 & 1.7 \\
\hline $\begin{array}{l}\text { Heating Change } \\
\text { Point }\left({ }^{\circ} \mathbf{F}\right)\end{array}$ & 58.3 & 58.4 & 6.0 & 46.9 & 69.7 & 55.0 & 54.2 & 1.9 & 50.9 & 59.1 \\
\hline $\begin{array}{l}\text { Cooling Change } \\
\text { Point }\left({ }^{\circ} \mathbf{F}\right)\end{array}$ & 67.5 & 67.6 & 5.3 & 57.0 & 77.8 & 65.3 & 66.5 & 1.8 & 63.3 & 69.4 \\
\hline $\begin{array}{l}\text { Base Load } \\
\text { (kWh/day) }\end{array}$ & 28.3 & 29.1 & 10.2 & 11.2 & 50.6 & 29.6 & 30.1 & 7.0 & 19.6 & 40.4 \\
\hline CV-RMSE & $12.5 \%$ & $12.5 \%$ & $3.1 \%$ & $6.8 \%$ & $18.5 \%$ & $43.8 \%$ & $50.0 \%$ & $51.0 \%$ & $32.0 \%$ & $77.7 \%$ \\
\hline
\end{tabular}

$\mathrm{n}$ is the number of houses.

BEopt default assumptions about how energy is consumed in the home will not specifically align with utility data "out of the gate." The results displayed in this report are preliminary calibration measures, where only limited ranges of inputs were tested. More runs that take into account differences in inverse models could be completed to better align the BEopt simulations to the utility data. For using the models to predict energy consumption, more calibration iterations would be necessary.

Table 29 compares the normalized annual energy consumption, calculated from the utility data, to BEopt simulation totals. Note that the number of inliers between the simulations and the utility data are different because the noise level is greatly reduced in simulations.

Table 29. Comparison of Annual Energy Consumption Statistics

\begin{tabular}{|c|c|c|c|c|c|}
\hline & \multicolumn{5}{|c|}{ Total Energy (kWh in 2011) } \\
\hline & 胥 & 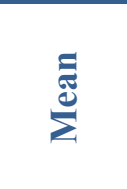 & 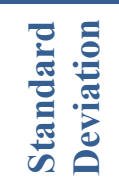 & 点 & 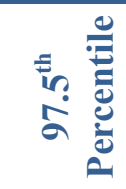 \\
\hline $\begin{array}{c}\text { Ranch Inliers ( } \mathrm{n}=937) \text { Daily Actual Utility Bill } \\
\text { IMT Results }\end{array}$ & 15,252 & 15,459 & 4,163 & 7,469 & 24,001 \\
\hline $\begin{array}{c}\text { Ranch Inliers }(n=1,009) \text { Daily BEopt Energy } \\
\text { Simulation IMT Results }\end{array}$ & 12,915 & 12,994 & 2,542 & 9,006 & 16,750 \\
\hline \% Difference Between BEopt and Utility Bills & $15.3 \%$ & $15.9 \%$ & $38.9 \%$ & $-20.6 \%$ & $30.2 \%$ \\
\hline
\end{tabular}

$\mathrm{n}$ is the number of houses. 


\section{Conclusions}

This project was designed to create a baseline of pre-retrofit information about houses that will be retrofitted during the coming years. These data then could be used in the future to compare actual energy consumption of the post-retrofit houses against the pre-retrofit case and the predicted savings associated with those measures as calculated by BEopt (BEopt 2013). The simple processes discussed here can be used to create big-picture overviews of building portfolios as an initial step in producing baseline models for a community of homes from which energy savings can be projected. Also, the estimated disaggregation of the whole-house energy data can be used to sort homes by their energy consumption profiles, which can aid in the selection of homes for additional audits.

This project has addressed the research questions as explained in the following paragraphs.

\section{How can the consumption data of each home be screened to identify changes in occupancy?}

Changes in occupancy cause the five-parameter model to inadequately represent the data as indicated in the GOF measures. Therefore, the project team performed sliding regressions to select only results from date ranges that pass all filtering thresholds. With a single model per home and with every home in the set using the same dates for analysis, $30 \%$ of the homes passed all GOF criteria for daily and monthly data. Only full years were run, and selectively removing abnormal data points such as unoccupied periods would theoretically increase the number of passing homes; however, this was not tested. With all 1-year intervals within a 3-year span modeled, 93\% of homes had at least 1 full year of data that passed the GOF thresholds for monthly data and $82 \%$ for daily data.

With many models per home from sliding regressions, a distribution of results yields the range of behavior performance within a home in time. A range of modeled performance characteristics is a better way to look at the energy consumption of a home than single-point values because single-point values do not represent the full spectrum of behavior. For the community as a whole, the predictions may not be significantly skewed with only one model per home; however, for individual homes, the results can be misleading.

\section{How do inverse modeling results vary between those using daily data and those using monthly data?}

Monthly and daily interval utility data were modeled using the five-parameter change-point linear model from the IMT. The models created with monthly input data predicted wider distributions of the five parameters than those with daily input data. However, in general, there were insignificant differences between IMT results using monthly and daily input data. The mean and median cooling slopes were comparable. Balance point temperatures shifted downward from monthly to daily data. Base-load estimates were more conservative with the daily data, with the results on average being lower than those made with monthly data. For simple weather normalization, monthly data results on average very closely aligned with daily data results. 
3. What is the variation in regression models of the heating and cooling energy slopes and change-point temperatures using daily or monthly utility bills when houses in a community are grouped by floor plan, orientation, square footage, and number of occupants?

Once houses were grouped by plan type and square footage, the differences in the results became more pronounced. The small and medium-sized houses were all ranch plan types that were built in the same era to the same specifications. Similarly, the larger houses were all duplex plan types that were built to meet ENERGY STAR ${ }^{\circledR}$ Version 1 criteria. As such, a noticeable difference was found between the IMT results for the houses when grouped in this way. There was variation in the results for houses when grouped by orientation, but it did not necessarily follow a pattern that could be attributed specifically to orientation effects. The south orientation had the greatest baseload deviation below the mean $(3.4 \mathrm{kWh} /$ day less $)$, and the north orientation had the greatest deviation above the mean $(5.3 \mathrm{kWh}$ /day more $)$; however, there was no clear pattern as the front of the house shifted around the cardinal orientations. Further analysis may be useful to subdivide the houses by plan type and then overlay orientation because the aggregation of all houses may be masking orientation effects.

Grouping by occupancy appeared to have the greatest impact on base load and heating slope, but the results should be "taken with a grain of salt." Only energy data were known in time. The occupancy data were single-point measurements, and it is not known how those data may have changed over the 3-year period.

\section{How do inverse models of simulated energy use from BEopt compare to inverse models of utility bills?}

The largest variation in results was seen in the heating and cooling slopes. The IBACOS team suspects that the nameplate efficiency of the HVAC system as input into BEopt was questionable, given the large discrepancy between simulation cooling slopes and utility data cooling slopes. Even when airtightness and thermostat set points were varied along with MELs, the BEopt heating and cooling slope results were $13 \%$ and $35 \%$ different, respectively, from the utility data.

\section{What efficiency characteristics and energy upgrade opportunities can be inferred from inverse modeling?}

Within this dataset of all-electric homes, inverse modeling appears to provide insight into the actual operational characteristics of the space conditioning systems and occupant behavior. All data provided to IBACOS indicated that these houses were built and maintained in a production fashion; therefore, one would not expect a large variation in thermal enclosure characteristics and space conditioning systems by community. Houses with steeper than normal heating and cooling slopes may be candidates for immediate intervention because their equipment may be failing. Houses with average cooling slopes and high heating slopes may be using excessive electric resistance heat, which may indicate a control problem or an occupant-initiated use of the resistance heat caused by aggressive setup/setback or to maintain comfort. 
Base-load variation indicated a wide range of usage across housing type, size, and occupancy. There appears to be a significant opportunity for occupant education across all houses as a means of reducing base load because there was a $7.4-\mathrm{kWh} /$ day standard deviation on a mean usage of $26.50 \mathrm{kWh} /$ day, with the 2.5 th percentile at $13.40 \mathrm{kWh}$ /day and the 97.5 th percentile at $42.40 \mathrm{kWh} /$ day. Audits also found that domestic hot water consumption could be lowered through the use of low-flow fixtures, although this cannot be inferred directly from the inverse modeling results.

\section{How do statistical methods compare to more traditional methods of physical energy audits?}

Statistical methods disaggregate the whole-house energy data into their major parts: heating, cooling, and base load. These energy consumption categories are derived from models with reasonable fits to the measurements; from the results, assumptions can be made about the possible causes of higher or lower energy consumption. Base-load energy naturally will vary from home to home and is primarily driven by occupant behavior. Cooling and heating use will vary by thermostat set points and other factors controlled by occupants, as well as static building and equipment characteristics. The insights derived from inverse models will enable targeted retrofits seeking "low-hanging fruit."

Typical audits do not study the consumption in time and rely on single-point measurements. Static pictures of energy consumption can be misleading, as exemplified by the differences between results of single years of data and distributions of performance over 3 years of data.

Typical energy audits require field testing and submetering of homes, incurring significant costs. The time in the field and the skill required to do the analysis properly are expensive. This project did not seek to quantify the necessity of additional auditing for this community; instead, it illustrates the types of information that can be gleaned from simple whole-house data. With available utility and building data, the simple inverse modeling approach to weather normalization is very fast, requiring no travel and no expensive software. Although physical audits will obtain detailed information useful for one house, at the community level, that detail is not warranted. If robust savings estimates were to be a goal, much more significant model calibration would occur to align the BEopt simulations to the utility bills. Inverse modeling would be helpful in combination with auditing to be able to select homes for auditing from the distribution of observed performance rather than a random selection of homes.

\subsection{Future Work}

There is a question of how to predict energy savings using this information. Inverse modeling could be helpful to use as an interpolation mapping so only a limited number of calibrated simulations need to be created to forecast savings. This would minimize the need for timeintensive simulations for every home in a large population, thus reducing analysis costs.

In this project, only a five-parameter model was used on full years of data. Most projects will likely have only 1 year of data with which to work. Further analysis could be done to develop a method for automatically removing anomalous data points. Three-parameter models of part-year data may adequately model individual seasons, for example. Daily data, with its significantly 
higher number of samples, will potentially exhibit an advantage over monthly data, where only 1 or 2 months of data could be removed before the quantity of data is insufficient.

Also, as the ongoing retrofits are completed, predictions can be verified and compared using the baseline models described in this report. 


\section{References}

ASHRAE (2002). ASHRAE Guideline 14-2002. Measurement of Energy and Demand Savings. Atlanta, GA: ASHRAE.

ASHRAE (2009). Data-Driven Modeling. 2009 ASHRAE Handbook-Fundamentals. Atlanta, GA: ASHRAE.

BEopt (2013). Building Energy Optimization with Hour-by-Hour Simulations, Version 2.0.0.3. Golden, CO: National Renewable Energy Laboratory. http://beopt.nrel.gov/.

BESTEST-EX (2013). Building Energy Simulation Test for Existing Homes (BESTEST-EX). Golden, CO: National Renewable Energy Laboratory. www.nrel.gov/buildings/bestest ex.html.

BPI (2012). ANSI/BPI-2400-S-2012: Standard Practice for Standardized Qualification of Whole-House Energy Savings Predictions by Calibration to Energy Use History. Malta, NY: The Building Performance Institute, Inc. Accessed November 7, 2014: www.bpi.org/Web\%20Download/BPI\%20Standards/BPI-2400-S2012 Standard Practice for Standardized Qualification of WholeHouse \%20Energy\%20Savings_9-28-12 sg.pdf.

Casey, S.; Krarti, M.; Bianchi, M.; Roberts, D. (2010). Identifying Inefficient Single-Family Homes with Utility Bill Analysis. Presented at ASME 4th International Conference on Energy Sustainability, Phoenix, AZ, May 17-22, 2010. Golden, CO: National Renewable Energy Laboratory, NREL/CP-550-47994. Accessed November 7, 2014: www.nrel.gov/docs/fy10osti/47994.pdf.

Eger, B.; Kissock, K. (2007). "Understanding Industrial Energy Use through Sliding Regression Analysis.” ACEEE Summer Study on Energy in Industry, White Plains, NY, July 24-27, 2007.

EnergyPlus (2013). EnergyPlus Energy Simulation Software, Version 7.2.0. http://apps1.eere.energy.gov/buildings/energyplus/.

Hendron, R.; Engebrecht, C. (2010). Building America House Simulation Protocols. Golden, CO: National Renewable Energy Laboratory, NREL/TP-550-49246. Accessed November 7, 2014: www.nrel.gov/docs/fy110sti/49246.pdf.

Kissock, J.K; Haberl, J.S.; Claridge, D.E. (2002). Development of a Toolkit for Calculating Linear, Change-Point Linear and Multiple-Linear Inverse Building Energy Analysis Models, Final Report. ASHRAE Research Project 1050-RP, November 1, 2002. Atlanta, GA: ASHRAE. Accessed November 7, 2014: http://repository.tamu.edu/bitstream/handle/1969.1/2847/ESL-TR02-11-02.pdf? sequence $=1$.

Python (2012). Python programming language, Version 3.2.3. Beaverton, OR: Python Software Foundation. Accessed November 7, 2014: http://python.org/about/.

Reddy, T.A.; Maor, I. (2006). Procedures for Reconciling Computer-Calculated Results with Measured Energy Data, Final Report. ASHRAE Research Project 1051-RP, January 2006.

Philadelphia, PA: ASHRAE. Accessed November 7, 2014:

www.pages.drexel.edu/ reddyta/ASHRAE_RP1051.pdf. 
buildingamerica.gov

Us. ofenaryutur of ENERGY

Energy Efficiency \& Renewable Energy 